\title{
RELATION OF TRIHALOMETHANE-FORMATION POTENTIAL TO WATER-QUALITY AND PHYSICAL CHARACTERISTICS OF SMALL WATER-SUPPLY LAKES, EASTERN KANSAS
}

By Larry M. Pope, Joseph A. Arruda, and Carla Hyde Fromm

U.S. GEOLOGICAL SURVEY

Water-Resources Investigations Report 88-4161

Prepared in cooperation with the

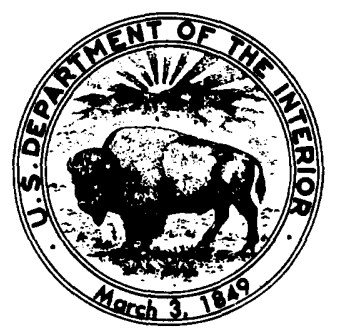

KANSAS DEPARTMENT OF HEALTH AND ENVIRONMENT

Lawrence, Kansas

1988 


\section{DEPARTMENT OF THE INTERIOR \\ DONALD PAUL HODEL, Secretary \\ U.S. GEOLOGICAL SURVEY \\ Dallas L. Peck, Director}

For additional information

write to:

District Chief

U.S. Geological Survey

1950 Constant Avenue - Campus West

Lawrence, Kansas 66046
Copies of this report can be purchased from:

U.S. Geological Survey Books and Open-File Reports Box 25425, Bldg. 810

Denver Federal Center

Denver, Colorado 80225 


\section{CONTENTS}

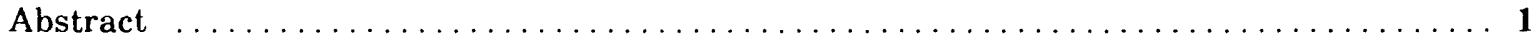

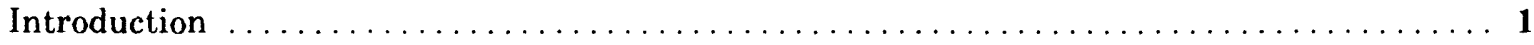

Description of study area and selected water-supply lakes $\ldots \ldots \ldots \ldots \ldots \ldots \ldots \ldots \ldots$

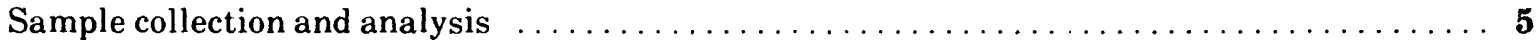

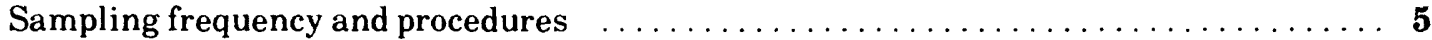

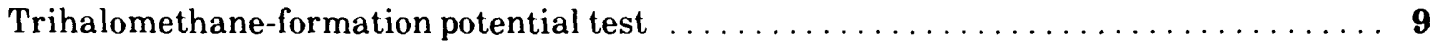

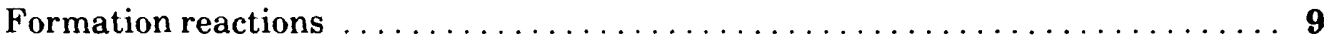

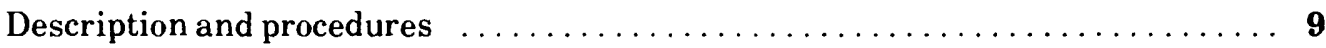

Analytical results and statistical analysis of data $\ldots \ldots \ldots \ldots \ldots \ldots \ldots \ldots \ldots \ldots \ldots \ldots$

Relation of trihalomethane-formation potential to water-quality characteristics $\ldots \ldots \ldots \ldots \quad 19$

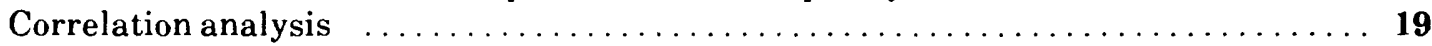

Simple linear-regression analysis $\ldots \ldots \ldots \ldots \ldots \ldots \ldots \ldots \ldots \ldots \ldots \ldots \ldots \ldots$

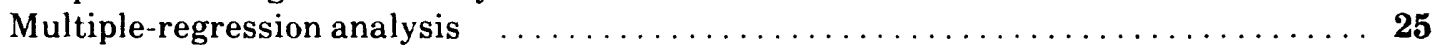

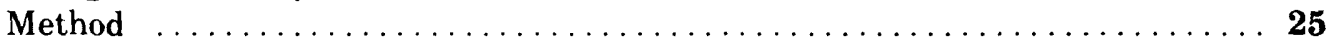

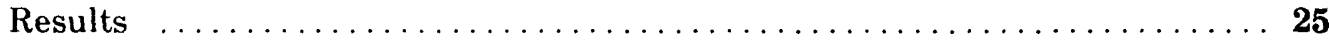

Relation of trihalomethane-formation potential to physical characteristics of lakes and

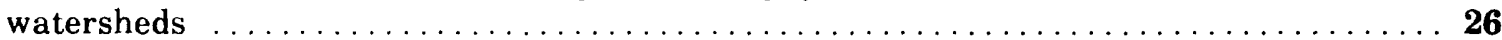

Correlation and simple linear-regression analysis $\ldots \ldots \ldots \ldots \ldots \ldots \ldots \ldots \ldots \ldots$

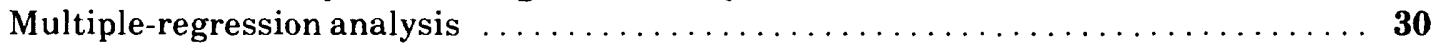

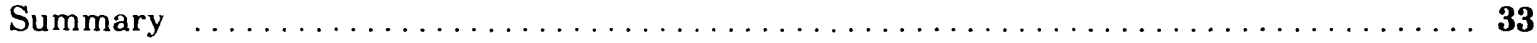

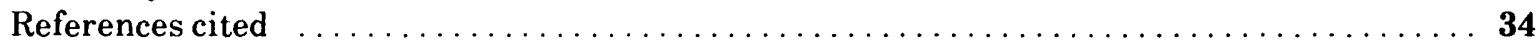

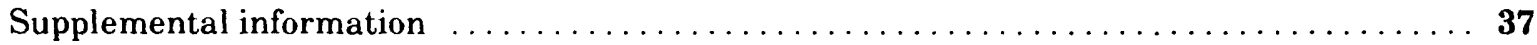

ILLUSTRATIONS

Figures 1 - 4.--Maps showing:

1. Location of study area and selected water-supply lakes $\ldots \ldots \ldots \ldots \ldots \ldots \ldots$

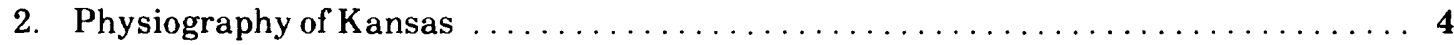

3. Mean annual precipitation in Kansas, $1951-80 \ldots \ldots \ldots \ldots \ldots \ldots \ldots \ldots \ldots$

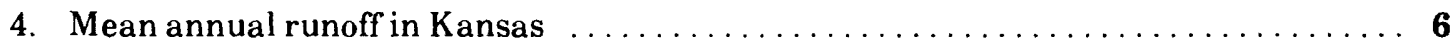

Figures 5 - 12--Graphs showing:

5. Percentages of chloroform, dichlorobromomethane, chlorodibromomethane, and bromoform in mean concentrations of total trihalomethanes formed during maximum trihalomethane-formation potential test in unfiltered surface water, filtered surface water, unfiltered bottom water, and filtered bottom water

6. Comparison of mean concentrations of total trihalomethanes formed during maximum trihalomethane-formation potential test in unfiltered and filtered samples of surface and bottom water

7. Frequency distribution of concentrations of total organic carbon and dissolved organic carbon in all study lakes 
8. Frequency distribution of concentrations of total trihalomethanes formed during maximum formation-potential test in unfiltered and filtered samples of water from all

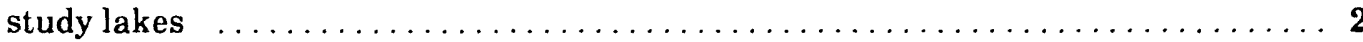

9. Relations between mean concentrations of trihalomethanes formed in unfiltered and filtered lake water and mean concentrations of total organic carbon

10. Relations between mean concentrations of trihalomethanes formed in unfiltered and filtered lake water and mean concentrations of dissolved organic carbon

11. Relations between mean concentrations of trihalomethanes formed in unfiltered and filtered lake water and mean maximum depth of lake

12. Relations between mean concentrations of total and dissolved organic carbon and mean maximum depth of lake

\section{TABLES}

Table

1. Map-index number, principal city using water, and location of water-supply lakes .. 7

2. Physical characteristics of water-supply lakes and watersheds, 1984

3. Water-quality measurements and chemical constituents, units of measurement, and analytical detection limits and responsibilities

4. Trihalomethane species, unit of measurement, and analytical detection limits as reported by the U.S. Geological Survey's laboratory, Arvada, Colorado

5. Descriptions and variable names of water-quality measurements and chemical constituents listed in tables 6,16 , and 17

6. Statistical summary of water-quality measurements, concentrations of chemical constituents, and concentrations of trihalomethanes formed during the maximum trihalomethane-formation potential test for lake-water samples collected at all 15 study lakes

7. Selected water-quality characteristics of water-supply lakes used in Pearson product-moment correlation analysis

8. Mean values of selected water-quality characteristics for $\mathbf{1 5}$ water-supply lakes ...

9. Pearson product-moment correlation coefficients and levels of significance of selected water-quality characteristics for 15 water-supply lakes

10. Summary of stepwise multiple-regression procedure relating mean concentrations of trihalomethane-formation potential in unfiltered lake water to mean concentrations of dissolved organic carbon and total phosphorus for 15 water-supply lakes 


\section{CONTENTS--Continued}

Table

Page

11. Regression equation for estimating mean concentrations of trihalomethaneformation potential in unfiltered lake water from mean concentrations of dissolved organic carbon and total phosphorus in 15 water-supply lakes

12. Selected water-quality characteristics and physical characteristics of lakes and watersheds used in Pearson product-moment correlation analysis

13. Pearson product-moment correlation coefficients and levels of significance for selected water-quality characteristics and physical characteristics of lakes and watersheds for 15 water-supply lakes

14. Summary of stepwise multiple-regression procedure relating mean concentrations of trihalomethane-formation potential in unfiltered and filtered lake water and total and dissolved organic carbon to physical characteristics of lakes and watersheds for 15 water-supply lakes

15. Regression equations for estimating mean concentrations of trihalomethaneformation potential in unfiltered and filtered lake water and mean concentrations of dissolved organic carbon from mean maximum depth of lake and percentage of watershed in ungrazed grassland for 15 water-supply lakes

16. Results of water-quality measurements and chemical analyses of water samples from six primary water-supply lakes $\ldots \ldots \ldots \ldots \ldots \ldots \ldots \ldots \ldots \ldots \ldots \ldots \ldots \ldots \ldots$

17. Results of water-quality measurements and chemical analyses of water samples from nine supplementary water-supply lakes

\section{CONVERSION FACTORS}

Inch-pound units of measurements used in this report can be converted to the International System of Units (SI) using the following conversion factors:

$\begin{array}{ll}\text { Multiply inch-pound units } & B y \\ \text { inch (in.) } & 2.54 \\ \text { foot (ft) } & 0.3048 \\ \text { mile } & 1.609 \\ \text { acre } & 0.4047 \\ \text { degree Fahrenheit }\left({ }^{\circ} \mathrm{F}\right) & (1)\end{array}$

\section{To obtain SI units}

centimeter

meter

kilometer

hectare

degree Celsius $\left({ }^{\circ} \mathrm{C}\right)$

${ }^{1}{ }^{\circ} \mathrm{C}=5 / 9\left({ }^{\circ} \mathrm{F}-32\right)$. 


\title{
RELATION OF TRIHALOMETHANE-FORMATION POTENTIAL TO WATER-QUALITY AND PHYSICAL CHARACTERISTICS OF SMALL WATER-SUPPLY LAKES, EASTERN KANSAS
}

\author{
By Larry M. Pope, Joseph A. Arruda, and Carla Hyde Fromm
}

\begin{abstract}
The formation of carcinogenic trihalomethanes during the treatment of public surface-water supplies has become a potentially serious problem. The U.S. Geological Survey, in cooperation with the Kansas Department of Health and Environment, investigated the potential for trihalomethane formation in water from 15 small, public water-supply lakes in eastern Kansas from April 1984 through April 1986 in order to define the principal factors that affect or control the potential for trihalomethane formation during the watertreatment process.
\end{abstract}

Relations of trihalomethane-formation potential to selected water-quality characteristics were investigated using correlation and simple and multiple-regression analysis. Regression equations significant at the 0.0001 level were developed to estimate mean concentrations of trihalomethanes formed in unfiltered and filtered lake water from mean concentrations of total and dissolved organic carbon. Correlation coefficients for these relations ranged from 0.86 to 0.93 , with standard errors of estimates of 13.6 and 9.9 percent of the mean of the dependent variable, respectively. Larger correlation coefficients and smaller standard errors of estimate were obtained with mean concentration of dissolved organic carbon as the independent variable.

Multiple-regression analysis produced a significant (at 0.0001 level) equation for estimating mean concentrations of trihalomethanes formed in unfiltered lake water from mean concentrations of dissolved organic carbon and total phosphorus. The coefficient of determination was 0.94 , with a standard error of estimate equal to 7 percent of the mean of the dependent variable.
Relations of mean concentrations of trihalomethane-formation potential and total and dissolved organic carbon to selected lake and watershed physical characteristics were investigated using correlation and simple- and multiple-regression analysis. Regression equations (significant at the 0.001 level) were developed to estimate mean concentrations of trihalomethane-formation potential and total and dissolved organic carbon from the mean maximum depth of a lake. Correlation coefficients for these relations ranged from -0.76 to -0.81 , with standard errors of estimate of 20.2 to 13.8 percent of the mean of the dependent variables, respectively.

Multiple-regression analysis improved the estimative power of the simple-regression equations to estimate the mean concentrations of trihalomethanes formed in unfiltered and filtered lake water and dissolved organic carbon with the addition of a second independent variable, percentage of watershed in ungrazed grassland. No additional physical characteristics were determined to be significant in estimating mean concentrations of total organic carbon.

\section{INTRODUCTION}

Many communities in eastern Kansas use small lakes as water-supply sources. Because the water is chlorinated, the formation of trihalomethanes (THMs) as by-products in the treatment of the water is a potentially serious problem. Knowledge of the relations among physical, chemical, and biological characteristics of lakes and THM-formation potential is fundamental so that necessary steps can be taken to protect drinking-water sources from the production of harmful substances.

Since the discovery of THMs in chlorinated 
drinking water in 1974 (Rook, 1974), epidemiological and toxicological investigations have determined that THMs may pose a health risk to humans (Cumming, 1978; Schneiderman, 1978; Simmon and Tardiff, 1978). As a result, the U.S. Environmental Protection Agency has established a maximum contaminant level of $100 \mu \mathrm{g} / \mathrm{L}$ (micrograms per liter) for THMs in drinking water (Catruvo, 1981).

Trihalomethanes are formed during the disinfection of water supplies with chlorine. As a result of chlorination, naturally occurring organic substances in water supplies are halogenated, and THMs consisting mainly of chloroform $\left(\mathrm{CHCl}_{3}\right)$, dichlorobromomethane $\left(\mathrm{CHCl}_{2} \mathrm{Br}\right)$, chlorodibromomethane $\left(\mathrm{CHClBr}_{2}\right)$, and bromoform $\left(\mathrm{CHBr}_{3}\right)$ are produced. The bromide-substituted products are thought to result from parallel bromination reactions initiated by the action of chlorine on background concentrations of bromide ion, which is present in most natural waters (Boyce and Hornig, 1983). The halogenation reactions are not instantaneous but occur during a few days until either the halogen or precursor material is depleted (Stevens and Symons, 1977).

The precursors of THM formation are part of the total organic carbon (TOC) present in surface water. Total organic carbon consists of a dissolved (DOC) component and a suspended (SOC) component. Dissolved organic carbon is defined operationally as that part of the TOC that passes through a 0.45 - $\mu \mathrm{m}$ (micrometer) silver-membrane filter, and SOC is that part of the TOC that is retained on the filter. Total organic carbon in streams and lakes is derived from two principal sources: (1) Organic matter originating outside the stream or lake (allochthonous), which includes leaf litter, soil leachates, and organic pollution; and (2) organic matter produced in the stream or lake by living organisms (autochthonous), which includes the decomposition of aquatic plants and animals, and cellular excretory products (Reid and Wood, 1976).

Studies have determined that the most common precursors of THM formation include the aquatic humic substances--fulvic and humic acids (Rook, 1977; Morris and Baum, 1978;
Noack and Doerr, 1978; Hoehn and others, 1980; Norwood and others, 1980; O'Brien and others, 1980; Peters and others, 1980). Humic substances are decay products of plant and animal tissue and constitute 40 to 60 percent of the DOC in natural water.

The source of aquatic humic substances may be allochthonous or autochthonous. Allochthonous humic substances may be produced by the leaching of plant organic matter through the soil profile and the leaching of soil fulvic and humic acids into water. Autochthonous humic substances may be produced by the lysis of algal cells, bacterial action on phytoplankton, and ultraviolet oxidation of surface-active organic matter, followed by polymerization reactions among various functional groups originating from biological products (Thurman, 1985 , p. 358). Generally, streams contain large quantities of allochthonous humic substances, whereas lakes may have a greater percentage of the total humic substances originating from autochthonous sources.

A correlation between TOC and THMformation potential of untreated source water was determined in a study in North Carolina (Singer and others, 1981). A similar correlation with TOC is expected in water-supply lakes in Kansas. Data collected during a recent waterquality reconnaissance of 19 water-supply lakes in eastern Kansas were used to develop a multiple-regression equation relating mean concentrations of TOC to physical characteristics of lakes that include maximum depth, surface area, age, and the ratio of watershed area to lake-surface area (Pope and others, 1985). Because TOC concentrations generally are larger in lakes with greater nutrient enrichment, it is expected that THMformation potential will be related to characteristics that control or enhance this enrichment. These characteristics include the physical features of the lakes and watersheds, chemical composition of the water, and biological productivity.

The U.S. Geological Survey and the Kansas Department of Health and Environment entered into a cooperative agreement in 1984 to investigate 15 selected small water-supply lakes in eastern Kansas in order to define the 
principal factors that affect or control the potential for THM formation during the watertreatment process. The specific objectives of the investigation were to determine the potential for THM formation in each study lake and to relate that potential to the physical, chemical, and biological characteristics of the lakes. This report presents the results of the investigation.

\section{DESCRIPTION OF STUDY AREA AND SELECTED WATER-SUPPLY LAKES}

The location of the study area and selected water-supply lakes are shown in figure 1 . The 43-county study area is in the eastern one-third of Kansas and is, for the most part, within the
Osage Plains, Flint Hills Upland, and Dissected Till Plains sections of the Central Lowland physiographic province (Schoewe, 1949), as shown in figure 2. Topography of the Osage Plains ranges from gently undulating, sandstone-capped hills in the southeast, to gently rolling plains of the central and eastern section, to the rugged chert and limestone surface features of the Flint Hills Upland along the western boundary. The Dissected Till Plains are, in reality, a northern extension of the Osage Plains; however, glacial drift from at least two Pleistocene ice intrusions has concealed much of the Osage Plains topography prevalent to the south. The typical rockcontrolled topography of the Osage Plains is absent in the Dissected Till Plains.

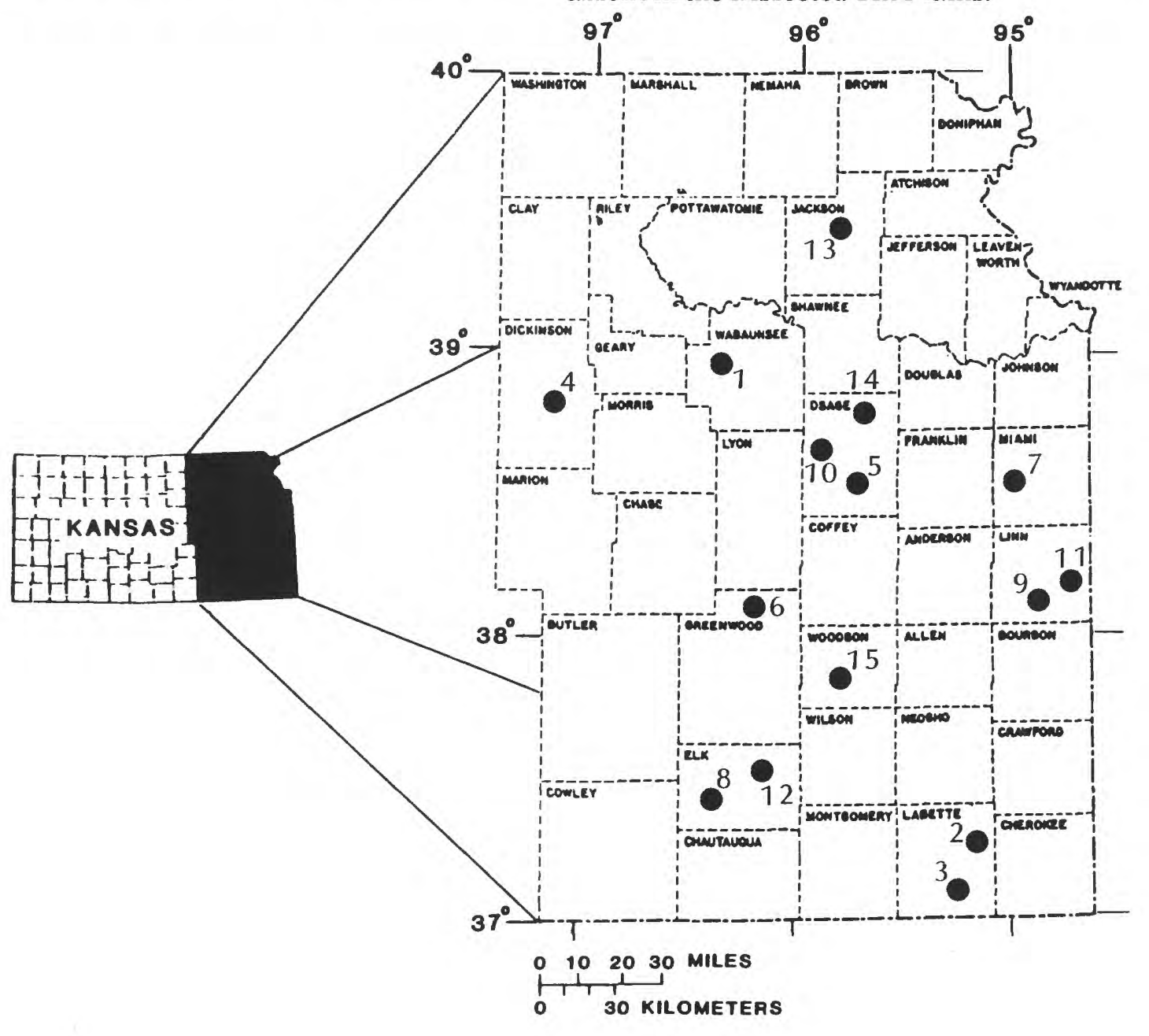

EXPLANATION

\section{STUDY LAKE AND MAP INDEX NUMBER}

Figure 1. Location of study area and selected water-supply lakes. 


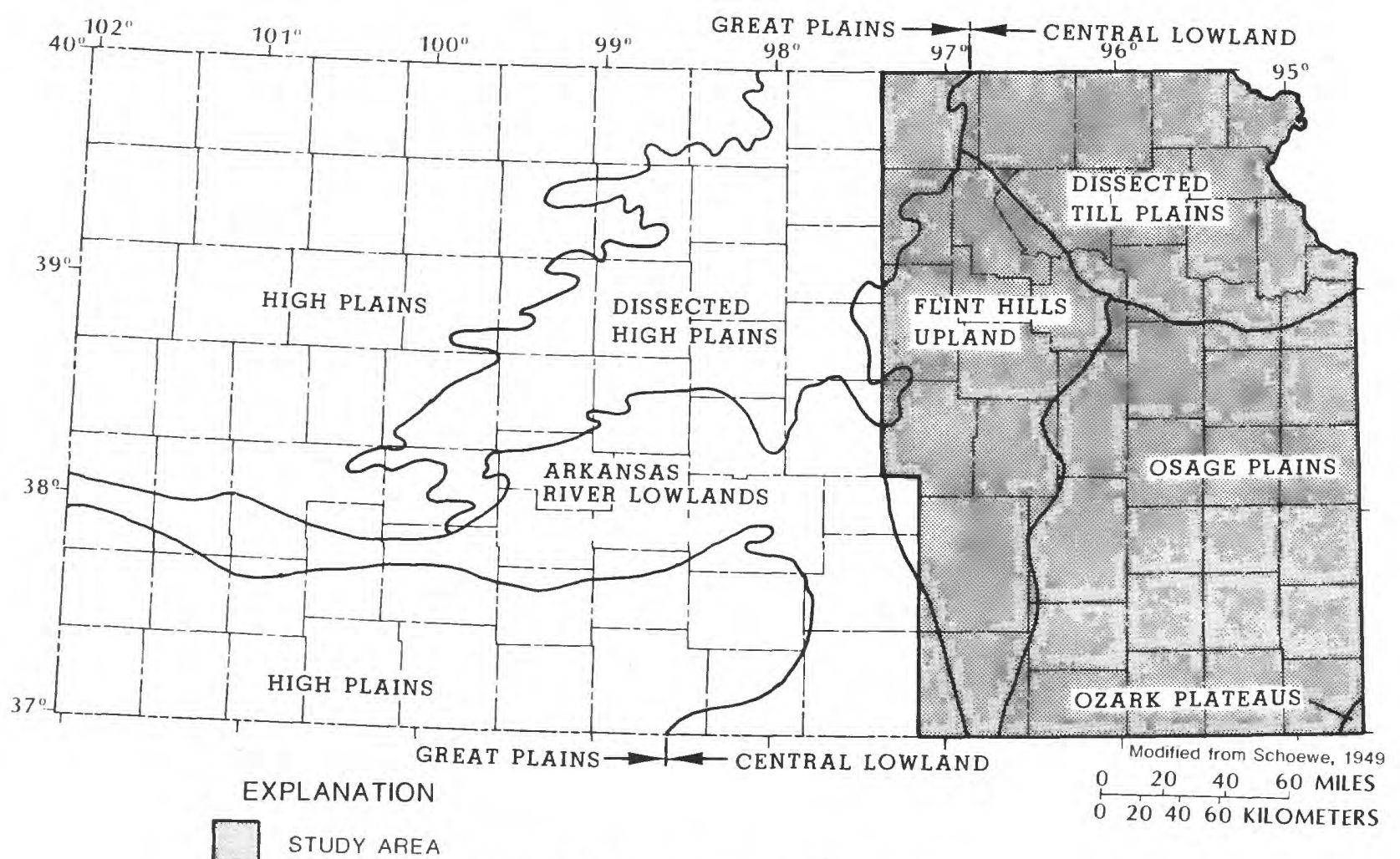

Figure 2. Physiography of Kansas.

Surface water (lakes and streams) is an important public-supply source for eastern Kansas. Of the State's approximately 2.4 million people, about one-half live in the study area. Surface-water sources provide about 70 percent of the water demands in this area (Kenny, 1986, p. 6). Because bedrock aquifers in eastern Kansas generally yield small quantities of water that is too mineralized for many uses and because annual precipitation and runoff rates are greatest in eastern Kansas, it is not surprising that most of the State's water-supply lakes are located in the study area. Mean annual precipitation across the State is shown in figure 3. Statewide, mean annual precipitation ranges from about 16 in. in the west to about 40 in. in the extreme southeast. Within the study area, mean annual precipitation ranges from about 30 to about 40 in. Mean annual runoff for Kansas varies greatly (fig. 4). Mean annual runoff increases in an easterly direction from a minimum of about $0.1 \mathrm{in}$. in the west to a maximum of about $10.0 \mathrm{in}$. in the southeast. Mean annual runoff in the study area ranges from about 3.5 to about 10.0 in. (Carswell, 1982).
Fifteen public water-supply lakes were selected for this investigation. Map-index numbers, the principal cities that use water from the lakes, lake-location descriptions, and the counties in which the lakes are located are provided in table 1. These $\mathbf{1 5}$ lakes are a subset of 19 water-supply lakes studied in a 1983 reconnaissance investigation (Pope and others, 1985). Water-supply lakes for the investigation described herein were selected to represent the range of physical characteristics of the 19 lakes and their watersheds studied during the 1983 investigation. These characteristics include age, lake-surface area, watershed area, mean maximum depth, and types of land use within each watershed (table 2 ).

Data for lake-surface area, watershed area, and watershed land-use classifications were provided by the U.S. Soil Conservation Service (written commun., 1984). Six watershed landuse classifications were identified for this investigation: (1) Protected cropland--cropland protected by soil-erosion control features, such as terraces and sedimentation ponds; (2) unprotected cropland--cropland lacking soil- 


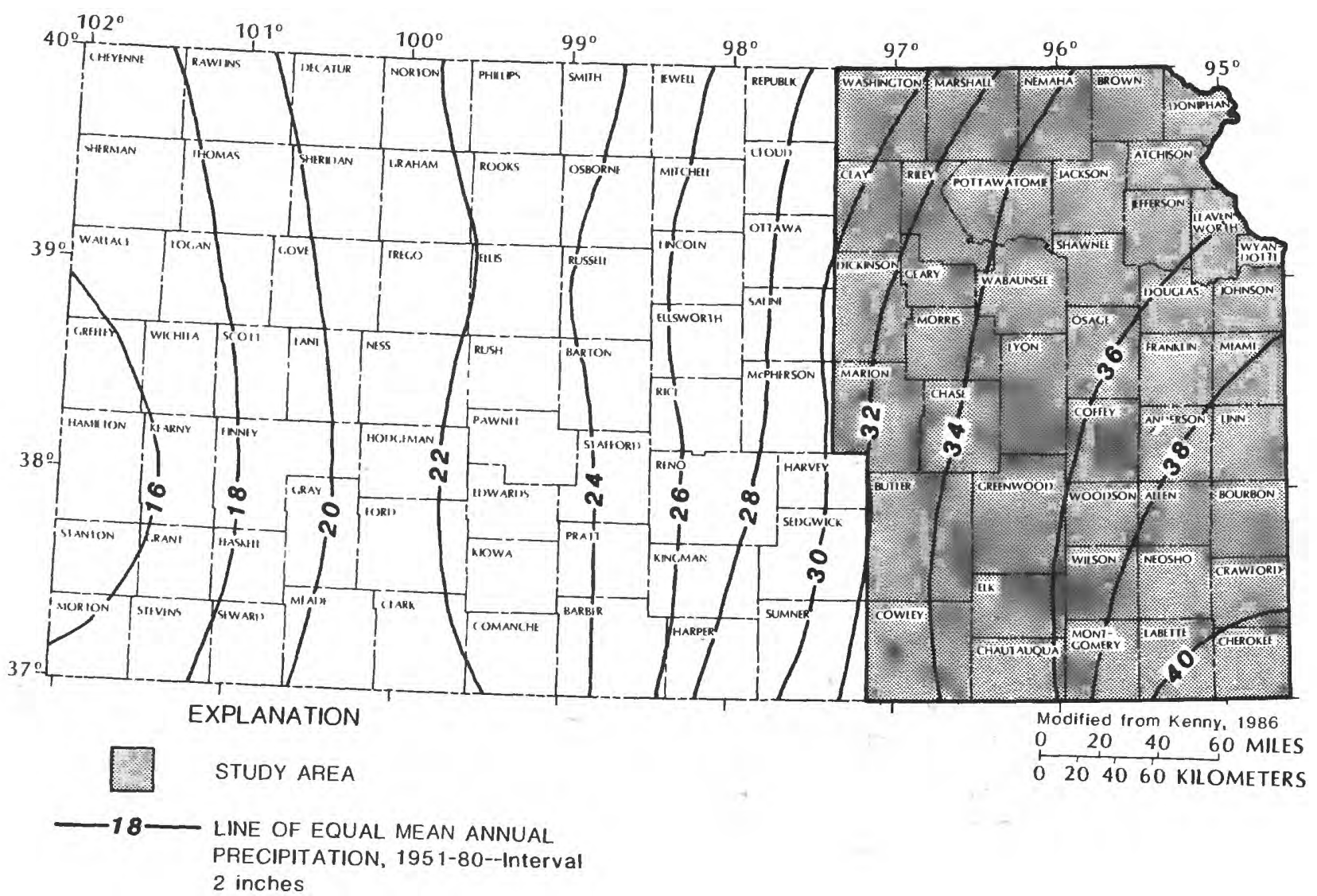

Figure 3. Mean annual precipitation in Kansas, 1951-80.

erosion control features; (3) grazed grassland-grassland used for pasturing of livestock; (4) ungrazed grassland--grassland mainly used for hay production; (5) forest land--land with trees as the predominate vegetative cover; and (6) other land use--includes urban areas, small industrial sites, animal feedlots, major roads and highways, ponds and small lakes, and recreational areas, such as golf courses, parks, and camping areas. Accuracy of lake-surface area and watershed-area data was verified by planimetric procedures using U.S. Geological Survey 7 1/2-minute topographic maps. The mean maximum depth of each lake is the mean depth of the sampling verticals recorded during sample-collection visits to the lakes. Sampling verticals were located offshore from the dam at the deepest point of each lake.

Of the 15 lakes chosen for this investigation, six were selected as "primary" lakes (table 1). The remaining nine lakes were designated as "supplementary" lakes. The six primary lakes were selected to represent a range in trophic level based on mean concentrations of chlorophyll- $a$, an indicator of algal biomass, determined during the 1983 reconnaissance investigation. Also, the primary lakes were selected to be a representative subset of the 15 study lakes with regard to physical characteristics of the lakes and watersheds. A comparison of mean values of physical characteristics for the six primary lakes and all 15 study lakes is provided at the bottom of table 2. An examination of these mean values indicates little practical difference between the 6-lake subset and all 15 study lakes. Primary lakes were sampled more frequently than supplementary lakes.

\section{SAMPLE COLLECTION AND ANALYSIS}

\section{Sampling Frequency and Procedures}

Samples for water-quality analyses at the six primary lakes were collected semimonthly, April through September 1984, and monthly, April through October 1985. Samples from the nine supplementary lakes were collected once in the spring, summer, and fall of 1985 . All 15 


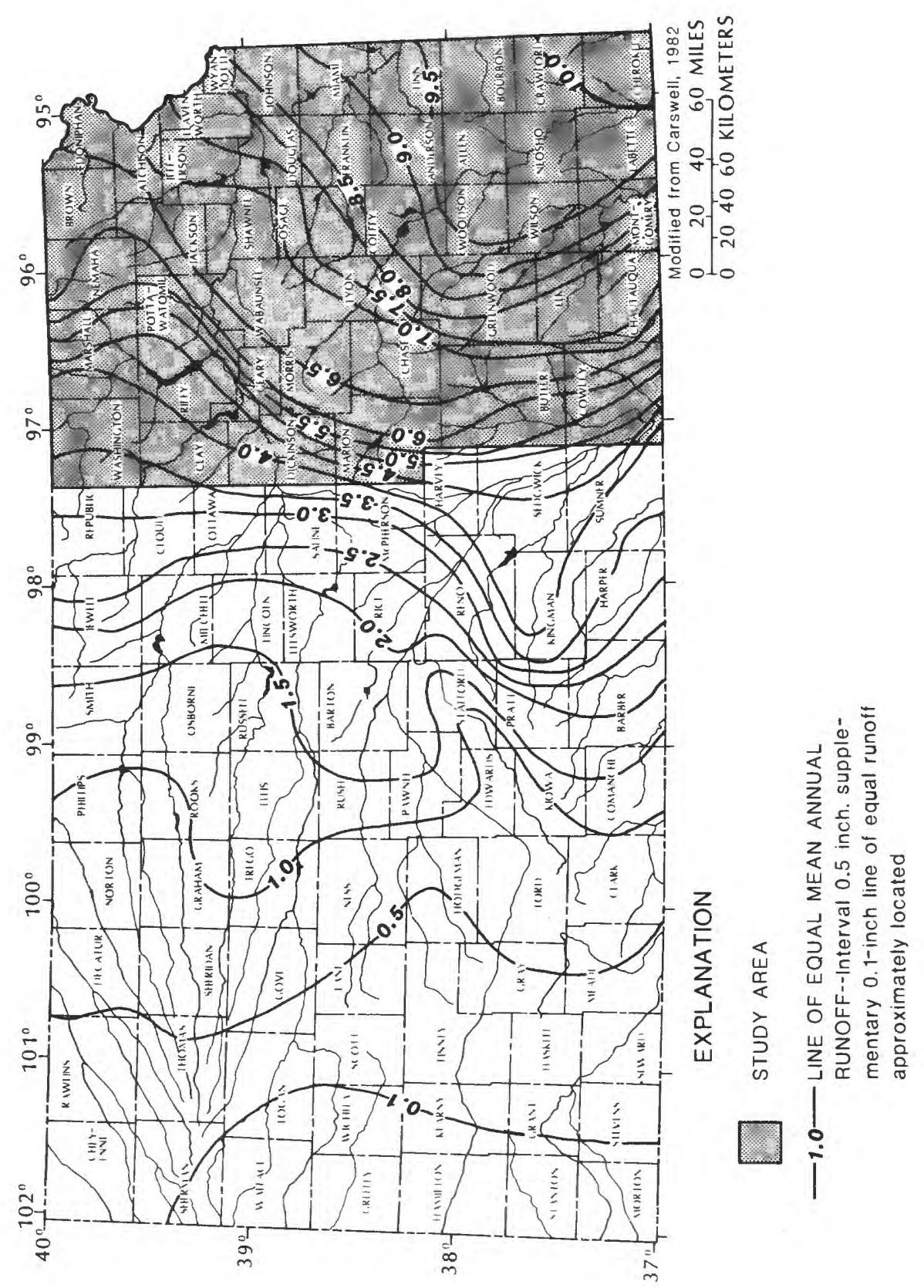

 


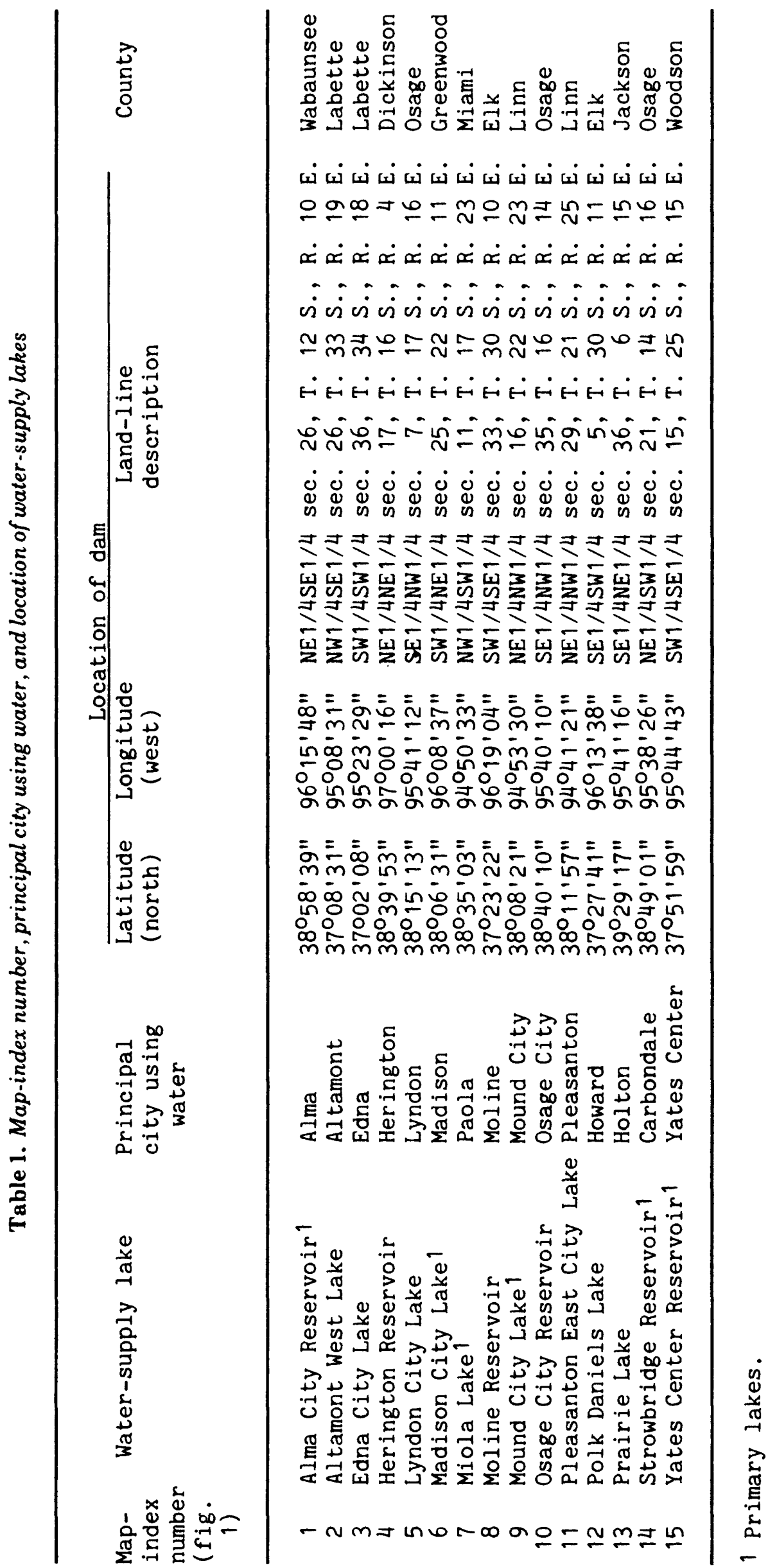




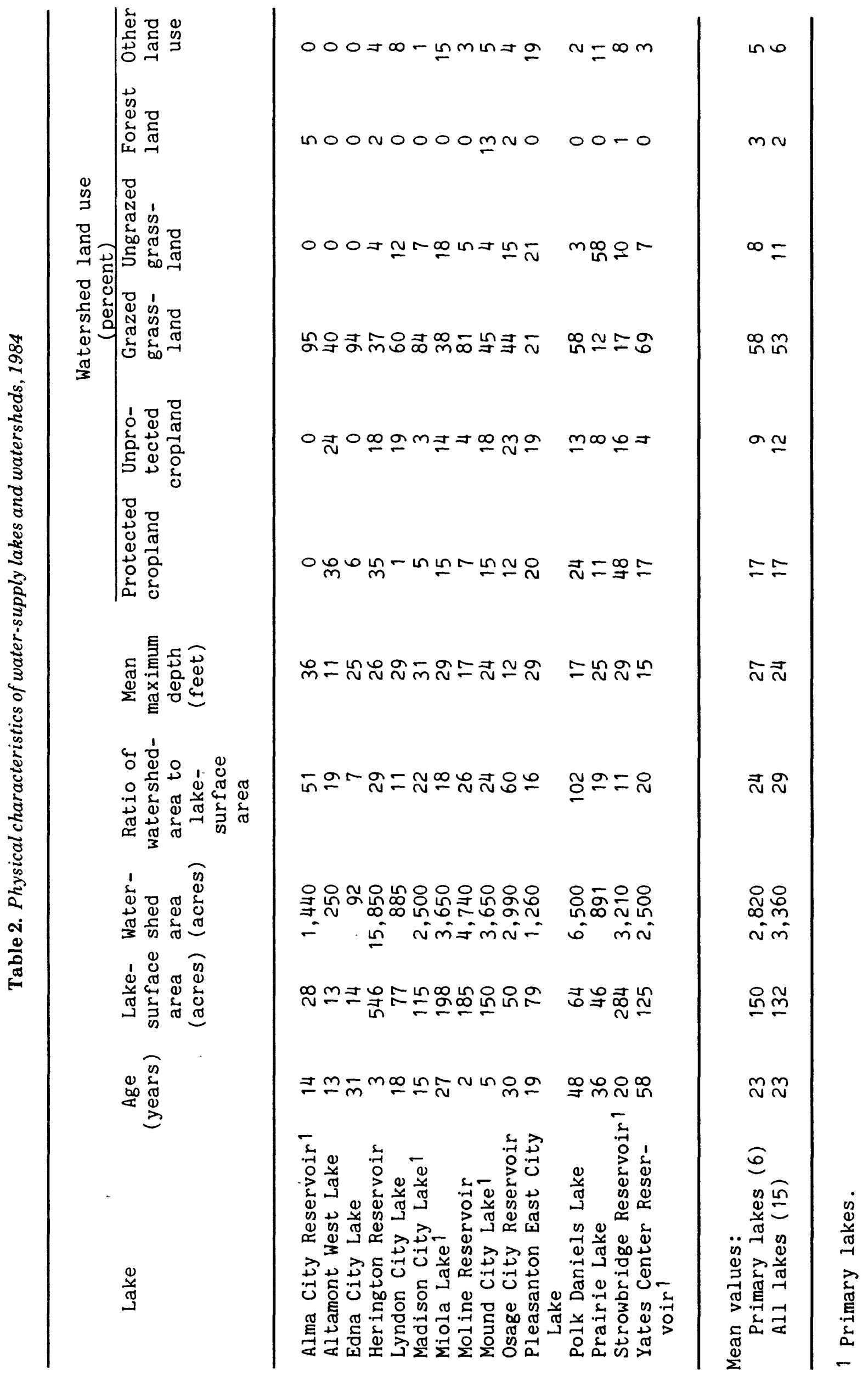


study lakes were sampled once in the spring of 1986. Samples were collected from a single vertical in each lake. A previous water-quality reconnaissance of small water-supply lakes (Pope and others, 1985) in which multiple sampling verticals were used, indicated only minor areal variation in water quality; therefore, it was believed that samples from a single vertical located offshore from the dam and at the deepest point of the lake would adequately define overall water quality. In all cases, samples were collected at the surface of the lake and at a point about 1.5 feet off the bottom. This dual sampling would define water-quality variation due to thermal stratification of the lakes. Vertical profiles of temperature and dissolved oxygen were obtained during all sampling visits in 1985 and 1986 and were made with a dissolved-oxygen meter. Specific conductance and $\mathrm{pH}$ were determined on topand bottom-collected samples.

Samples for water-quality analyses were collected according to procedures presented in Greeson and others (1977) and Skougstad and others (1979). A list of water-quality measurements and chemical constituents determined during this investigation is provided in table 3 . Chemical analyses of water samples by the Kansas Department of Health and Environment, Division of Laboratories, Topeka, Kansas, were made in accordance with methods described by the American Public Health Association (1975) or by the U.S. Environmental Protection Agency (1979a). Analysis of water samples for TOC and DOC were made by the U.S. Geological Survey, Arvada, Colorado, in accordance with procedures in Wershaw and others (1983, p. 22 27).

\section{Trihalomethane-Formation Potential Test}

\section{Formation Reactions}

The formation of THIMs is the result of the action of chlorine (OC1-) on DOC. According to Thurman (1985, p. 227), DOC is composed mostly of aquatic humic substances, which are oxidized according to the following generalized equation:

$\mathrm{OCl}^{-}+\mathrm{R} \cdot \mathrm{C} \cdot \mathrm{CH}_{3}(\mathrm{DOC})=\mathrm{CHCl}_{3}+\mathrm{R} \cdot \mathrm{C} \cdot \mathrm{OH}(\mathrm{DOC})$, where $\mathbf{R}$ may include aldehyde, phenols, and ketone.

In this equation, the chlorine, as $\mathrm{OCl}^{-}$, reacts with the DOC to produce chloroform $\left(\mathrm{CHCl}_{3}\right)$ and simultaneously oxidizes the DOC to carboxyl groups. The actual site of chlorine attack on DOC may be a resorcinol site (Rook, 1977) or, as proposed by Oliver and Thurman (1983), a chromophore-producing site of the humic molecule. In any event, the quantity of THM produced is dependent on the concentrations of chlorine and DOC present in the water.

\section{Description and Procedures}

To define the relation between THMformation potential and physical and waterquality characteristics of small water-supply lakes, it is necessary to determine THMformation potential with a method that will produce comparable results when applied to natural water from different lakes. To achieve comparability, a test developed by the U.S. Environmental Protection Agency was used in this investigation (Bellar and others, 1982). This test, maximum total trihalomethaneformation potential (MTTFP), was designed to yield THM concentrations larger than those that would normally be present in a waterdistribution system. Essentially, the test produces the maximum possible concentration of THMs during a 7-day incubation period after chlorination with a hypochlorite reagent.

As previously described, THM formation is a function of the concentrations of organic carbon and free chlorine and length of reaction time (incubation period). If allowed to proceed unrestricted, the THM formation will continue until either the supply of precursor material or chlorine is depleted. Therefore, to achieve a maximum THM-formation potential, initial chlorine concentrations in the test samples were of such magnitude that, at the end of the 7-day incubation period, a free chlorine residual of at least $0.2 \mathrm{mg} / \mathrm{L}$ (milligrams per liter) remained in the samples. Comparability of test results among all study lakes is achieved by maintaining a constant incubation period and a free chlorine concentration sufficient for the duration of the incubation period. A 7-day 
Table 3. Water-quality measurements and chemical constituents, units of measurement, and analytical detection limits and responsibilities

$\left[\mu \mathrm{S} / \mathrm{cm}\right.$, microsiemens per centimeter at 25 degrees Celsius; ${ }^{\circ} \mathrm{C}$, degrees Celsius; JTU, Jackson turbidity units; in., inches; $\mathrm{mg} / \mathrm{L}$, milligrams per liter; $\mu \mathrm{g} / \mathrm{L}$, micrograms per liter]

\begin{tabular}{|c|c|c|c|}
\hline $\begin{array}{l}\text { Water-quality measurement } \\
\text { or chemical constituent }\end{array}$ & $\begin{array}{l}\text { Unit of } \\
\text { measurement }\end{array}$ & $\begin{array}{l}\text { Analy- } \\
\text { tical } \\
\text { detection } \\
\text { limit }\end{array}$ & $\begin{array}{l}\text { Analy- } \\
\text { tical } \\
\text { responsi- } \\
\text { bility }\end{array}$ \\
\hline Specific conductance & $\mu \mathrm{S} / \mathrm{cm}$ & -- & $\begin{array}{l}\text { Onsite } \\
\text { etermination }\end{array}$ \\
\hline $\mathrm{pH}$ & Standard units & -- & Do. \\
\hline Temperature, water & $\mathrm{OC}$ & -- & Do. \\
\hline Turbidity & JTU & -- & KDHE 1 \\
\hline Transparency, secchi disk & in. & -- & $\begin{array}{l}\text { Onsite } \\
\text { determination }\end{array}$ \\
\hline Dissolved oxygen & $\mathrm{mg} / \mathrm{L}$ & -- & Do. \\
\hline Dissolved solids & do. & 1.0 & KDHE \\
\hline $\begin{array}{l}\text { Nitrite plus nitrate, } \\
\text { total as } \mathrm{N}\end{array}$ & do. & .01 & Do. \\
\hline Ammonia, total as $\mathrm{N}$ & do. & .01 & Do. \\
\hline Phosphorus, total as $\mathrm{P}$ & do. & .01 & Do. \\
\hline Iron, total & $\mu g / L$ & 10 & Do. \\
\hline Manganese, total & do. & 10 & Do. \\
\hline Organic carbon, total & $\mathrm{mg} / \mathrm{L}$ & .10 & USGS2 \\
\hline Organic carbon, dissolved & do. & .10 & Do. \\
\hline Chlorophyll-a & $\mu \mathrm{g} / \mathrm{L}$ & .10 & KDHE \\
\hline
\end{tabular}

1 Kansas Department of Health and Environment, Division of Laboratories, Topeka, Kansas.

2 U.S. Geological Survey, Arvada, Colorado.

incubation period was chosen to simulate typical resident time in a water-distribution system. Additionally, a constant water temperature of $25^{\circ} \mathrm{C}$ was maintained during the incubation period.

As described in Bellar and others (1982), the hypochlorite reagent used in the MTTFP test was prepared from a commercial solution of 5.25-percent sodium hypochlorite llaundry bleach) diluted with reagent-grade water and refluxed for 6 hours to remove existing TIIMs. From this stock hypochlorite solution, a buffered hypochlorite reagent was prepared. Boric acid, sodium hydroxide, and hypochlorite solution were combined and heated overnight in a convection oven at a temperature just less than the boiling point of water $\left(100{ }^{\circ} \mathrm{C}\right)$. After cooling, the free chlorine concentration of the combined buffered-hypochlorite reagent was determined. A volume of the combined reagent was added to each test sample. The volume added to each sample was sufficient to insure a free chlorine concentration in excess of $0.2 \mathrm{mg} / \mathrm{L}$. at the end of the 7-day incubation period. Initially, the volume of combined reagent necessary was determined through trial and error, but with experience and a knowledge of the organic-carbon concentration normally present in a particular lake water, the appropriate volume of reagent could be estimated with a good degree of reliability. At the end of incubation, the residual free chlorine concentration was determined. The test was considered valid only if the residual free chlorine 
concentration was greater than $0.2 \mathrm{mg} / \mathrm{L}$. Concentrations of THMs were not determined on invalid test samples.

If the concentration of residual free chlorine was equal to or greater than $0.2 \mathrm{mg} / \mathrm{L}$ after the incubation period, a sodium sulfite solution was added to deactivate the remaining free chlorine and end the THM-formation process. A representative, $40-\mathrm{mL}$ (milliliter) aliquot then was transferred from a sample bottle to a glass septum vial (completely filled), wrapped in aluminum foil to exclude light, packed in ice, and shipped to the U.S. Geological Survey's laboratory in Arvada, Colorado, where concentrations of individual THM species were determined (table 4). Samples were analyzed by gas chromatograph/mass spectrometry (GC/MS) and conformed to the U.S. Environmental Protection Agency's purgeables method 624 (1979b). A detailed description of the analytical method used in this investigation is presented in Wershaw and others (1983, p. 139-146).

Filtered and unfiltered lake-water samples for the MTTFP test were collected at the same time and frequency as samples for those properties and constituents listed in table 3 . However, samples of bottom water were not collected for the test in 1984. Filtered samples consisted of the filtrate, which passed through a $0.45-\mu \mathrm{m}$ silver-membrane filter. All samples for the test determination were collected in $100-\mathrm{mL}$ glass bottles that had been heated overnight at $350{ }^{\circ} \mathrm{C}$ to eliminate any trace-organic contamination.

\section{ANALYTICAL RESULTS AND STATISTICAL ANALYSIS OF DATA}

Descriptions and variable names of waterquality measurements and chemical constituents for which data were collected during this investigation are listed in table 5 . Data for these measurements and chemical constituents are presented in tables 16 and 17 in the "Supplemental Information" section at the end of this report. A statistical summary of these data is presented in table 6 . The statistical summary includes the number of measurements or analytical determinations $(\mathrm{N})$, mean, median, minimum, and maximum values, standard deviation, and skewness. Mean values of $\mathrm{pH}$ were not computed because $\mathrm{pH}$ is expressed in logarithmic units and represents the negative base-10 log of the hydrogen-ion activity in moles per liter. Standard deviation is a measure of the dispersion (spread) of the data values about their means. The larger the standard deviation the greater the dispersion about the mean. Skewness is a measure of the asymmetry of the frequency distribution of data values. In a positively skewed distribution, data values will be clustered at the lower end of the measurement scale with just a few data values in the upper end. Conversely, if the data values are clustered in the upper end with just a few in the lower end, the distribution is negatively skewed. A symmetrical distribution has a zero skew (Klugh, 1970).

An examination of data in table 6 indicates only small differences between surface and

Table 4. Trihalomethane species, unit of measurement, and analytical detection limits as reported by the U.S. Geological Survey's laboratory, Arvada, Colorado

[ $\mu \mathrm{g} / \mathrm{L}$, micrograms per liter]

\begin{tabular}{lcc}
\hline $\begin{array}{l}\text { Trihalomethane } \\
\text { species }\end{array}$ & Unit of measurement & $\begin{array}{c}\text { Analytical } \\
\text { detection limit }\end{array}$ \\
\hline Chloroform $\left(\mathrm{CHCl}_{3}\right)$ & $\mu \mathrm{L} / \mathrm{L}$ & 3.0 \\
Dichlorobromomethane $\left(\mathrm{CHCl}_{2} \mathrm{Br}\right)$ & do. & 3.0 \\
Chlorodibromomethane $\left(\mathrm{CHClBr}_{2}\right)$ & do. & 3.0 \\
Bromoform (CHBr3) & do. & 3.0 \\
\hline
\end{tabular}


Table 5. Descriptions and variable names of water-quality measurements and chemical constituents listed in tables 6,16 and 17

[ft, feet; $\mu \mathrm{S} / \mathrm{cm}$, microsiemens per centimeter at 25 degrees Celsius; ${ }^{\circ} \mathrm{C}$, degrees Celsius; JTU, Jackson turbidity units; in., inches; $\mathrm{mg} / \mathrm{L}$, milligrams per liter; $\mu \mathrm{g} / \mathrm{L}$, micrograms per liter]

Water-quality measurement or chemical constituent

Unit of
measurement
name

Maximum lake depth

Specific conductance, surface

Specific conductance, bottom

$\mathrm{pH}$, surface

$\mathrm{pH}$, bottom

Temperature, water, surface

Temperature, water, bottom

Turbidity, surface

Transparency, secchı disk

Dissolved oxygen, surface

Dissolved oxygen, bottom

Dissolved solids, surface

Dissolved solids, bottom

Nitrite plus nitrate, total as N, surface

Nitrite plus nitrate, total as $N$, bottom

Ammonia, total as $\mathrm{N}$, surface

Ammonia, total as $N$, bottom

Phosphorus, total as $P$, surface

Phosphorus, total as $P$, bottom

Iron, total, surface

Iron, total, bottom

Manganese, total, surface

Manganese, total, bottom

Organic carbon, total as C, surface

Organic carbon, total as $C$, bottom

Organic carbon, dissolved as $C$, surface

Organic carbon, dissolved as $\mathrm{C}$, bottom

Chloroform, total, formed in unfiltered surface water

Chloroform, total, formed in filtered surface water

Chloroform, total, formed in unfiltered bottom water

Chloroform, total, formed in filtered bottom water

Dichlorobromomethane, total, formed in unfiltered surface water

Dichlorobromomethane, total, formed in filtered surface water

Dichlorobromomethane, total, formed in unfiltered bottom water

\begin{tabular}{|c|c|}
\hline $\mathrm{ft}$ & MLD_FT \\
\hline$\mu \mathrm{S} / \mathrm{cm}$ & SC_SUR \\
\hline do. & SC_BOT \\
\hline Standard unit & PH_SUR \\
\hline do. & PH_BOT \\
\hline${ }^{\circ} \mathrm{C}$ & TEMP_SUR \\
\hline do. & TEMP_BOT \\
\hline JTU & TURB \\
\hline in. & TRANS_IN \\
\hline $\mathrm{mg} / \mathrm{L}$ & DO_SUR \\
\hline do. & DO_BOT \\
\hline do. & DS_SUR \\
\hline do. & DS_BOT \\
\hline do. & NO3_SUR \\
\hline do. & NO3_BOT \\
\hline do. & NH4_SUR \\
\hline do. & NH4_BOT \\
\hline do. & TP_SUR \\
\hline do. & $T P \_B O T$ \\
\hline$\mu g / L$ & $F E \_S U R$ \\
\hline do. & $F E \_B O T$ \\
\hline do. & MN_SUR \\
\hline do. & MN_BOT \\
\hline $\mathrm{mg} / \mathrm{L}$ & TOC_SUR \\
\hline do. & TOC_BOT \\
\hline do. & DOC_SUR \\
\hline do. & DOC_BOT \\
\hline$\mu g / L$ & $\mathrm{CHLO}_{-} \mathrm{SU}$ \\
\hline do. & $\mathrm{CHLO}_{2} \mathrm{SF}$ \\
\hline do. & $\mathrm{CHLO}_{-} \mathrm{BU}$ \\
\hline do. & $\mathrm{CHLO}_{-} \mathrm{BF}$ \\
\hline do. & DCBM_SU \\
\hline do. & DCBM_SF \\
\hline do. & $D_{C B M} B U$ \\
\hline
\end{tabular}


Table 5. Descriptions and variable names of water-quality measurements and chemical constituents listed in tables 6,16 , and 17 --Continued

Water-quality measurement or chemical constituent $\quad \begin{gathered}\text { Unit of } \\ \text { measurement }\end{gathered}$

Dichlorobromomethane, total, formed in filtered bottom water Chlorodibromomethane, total, formed in unfiltered surface water Chlorodibromomethane, total, formed in filtered surface water Chlorodibromomethane, total, formed in unfiltered bottom water Chlorodibromomethane, total, formed in filtered bottom water

Bromoform, total, formed in unfiltered surface water Bromoform, total, formed in filtered surface water Bromoform, total, formed in unfiltered bottom water Bromoform, total, formed in filtered bottom water Chlorophyll-a, surface

$\begin{array}{ll}\mu g / L & \text { DCBM_BF } \\ \text { do. } & \text { CDBM_SU } \\ \text { do. } & \text { CDBM_SF } \\ \text { do. } & \text { CDBM_BU } \\ \text { do. } & \text { CDBM_BF } \\ \text { do. } & \text { BROM_SU } \\ \text { do. } & \text { BROM_SF } \\ \text { do. } & \text { BROM_BF } \\ \text { do. } & \text { CHL_A_S } \\ \text { do. } & \end{array}$

bottom mean concentrations of TOC and DOC. Mean concentrations of TOC and DOC in bottom water for all 15 study lakes appear to be slightly Iarger (6.5 percent and 1.6 percent, respectively) than corresponding mean concentrations in surface water. To determine if these mean-concentration differences are statistically different from one another, a twotailed $t$-test was performed on the surface and bottom concentrations of TOC and DOC. A t-test is a statistical procedure that uses the means and standard deviations of two sample sets to test the difference between two means. Results of the t-tests indicated no significant differences (at the 0.05 level of significance) between surface and bottom concentrations of TOC or DOC. Therefore, for this set of 15 water-supply lakes, it appears that long-term (April 1984 through April 1986) surface and bottom mean concentrations of TOC and DOC are statistically equivalent.

Mean concentrations of THMs formed during the maximum formation-potential test are listed in table 6. By far, chloroform $\left(\mathrm{CHCl}_{3}\right)$ is the predominant THM species formed during the formation-potential test. Mean concentrations of chloroform are at least one order of magnitude larger than mean concentrations of any other THM species in all four formation-test categories (unfiltered surface water, filtered surface water, unfiltered bottom water, and filtered bottom water). The predominance of chloroform is illustrated in figure 5 , where THM species are represented as a percentage of the mean total THM concentration (summation of mean concentrations of the four THM species) in each formation test category. Chloroform represents 92 percent of the mean total THM formation in unfiltered surface water, 98 percent in filtered surface water, 93 percent in unfiltered bottom water, and 98 percent in filtered bottom water, for an average of 95 percent in all categories. Dichlorobromomethane $\left(\mathrm{CHCl}_{2} \mathrm{Br}\right)$ averaged 4.3 percent for the four test categories, whereas the average for chlorodibromomethane $\left(\mathrm{CHClBr}_{2}\right)$ was 0.4 percent. No bromoform $\left(\mathrm{CHBr}_{3}\right)$ was detected.

Mean concentrations of total THMs (summation of the means of the individual THM species listed in table 6), on first examination, appear to be largest in tests conducted with water obtained from near the bottom of the lakes in both unfiltered and filtered test samples. For instance, mean concentrations of total THMs formed in unfiltered bottom water were 7.3 percent larger than the mean concentrations in unfiltered surface water. Similarly, the mean concentrations of total THMs in filtered bottom water were 10 percent larger than the mean concentrations in filtered surface water. However, when these paired means were subjected to a t-test analysis, it was determined that there were no significant differences (at the 0.05 level) between mean concentrations of total THMs formed in surface and bottom samples for either unfiltered or filtered lake water. 


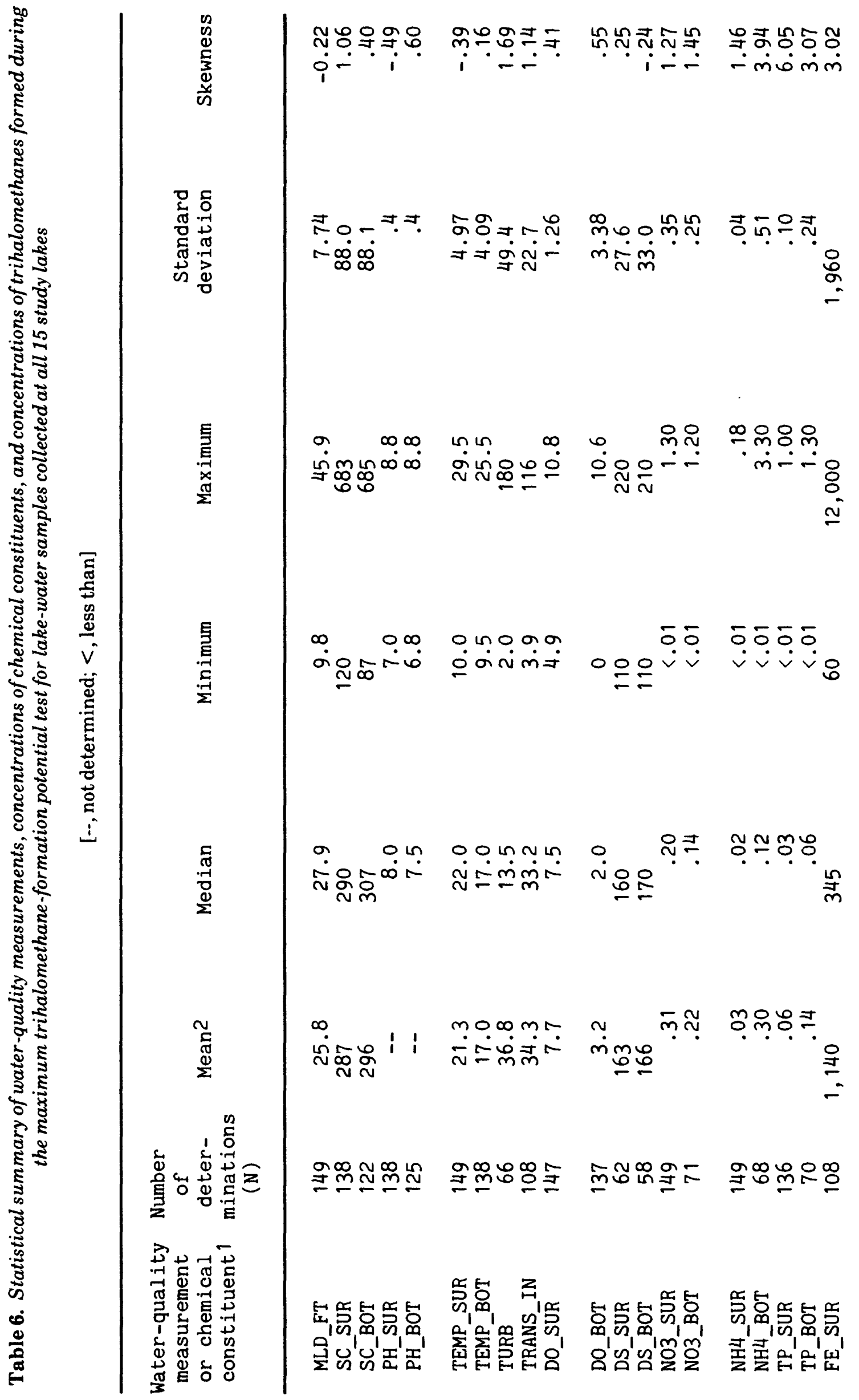




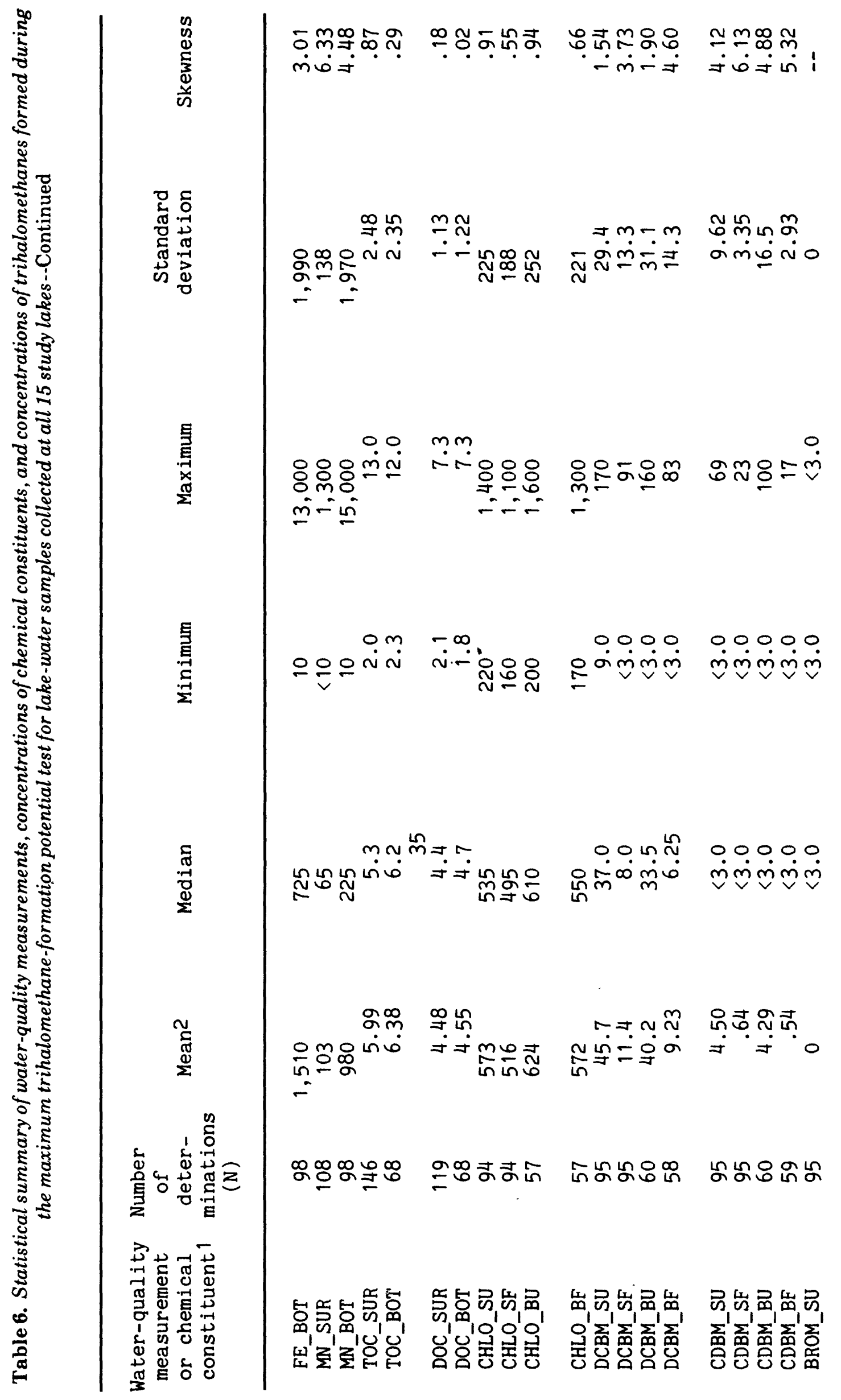




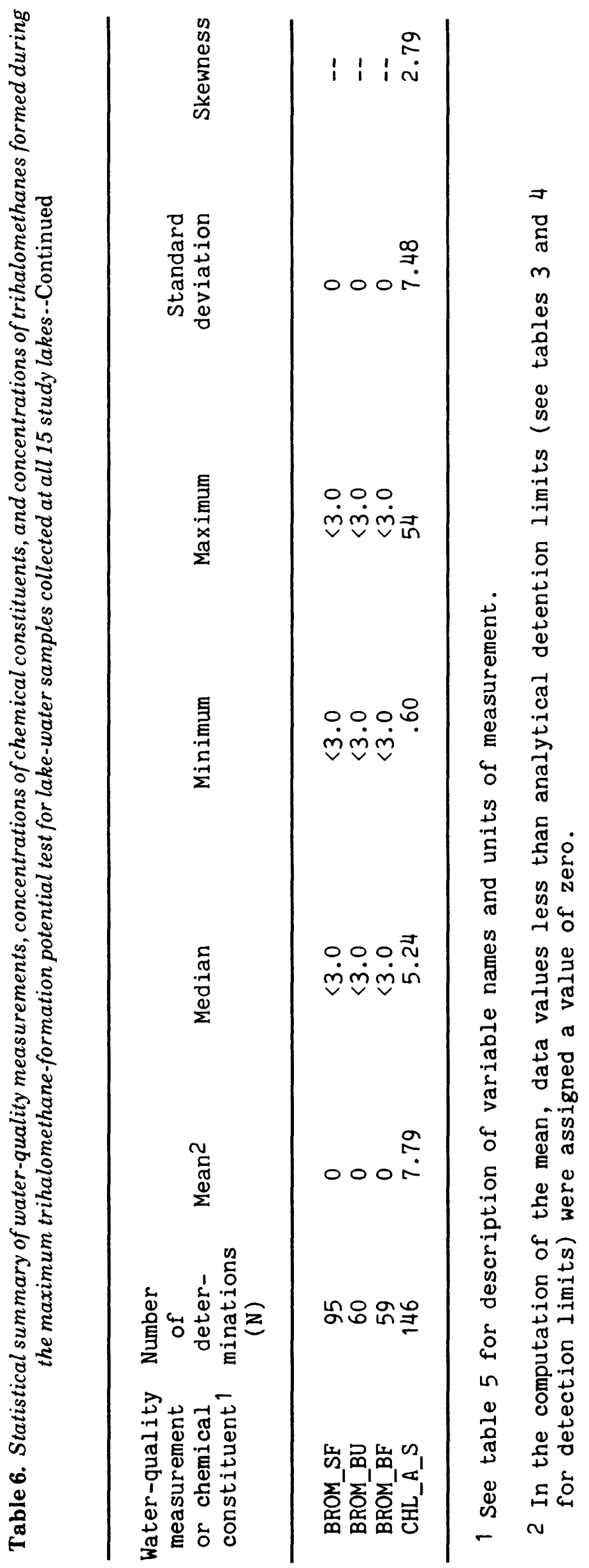




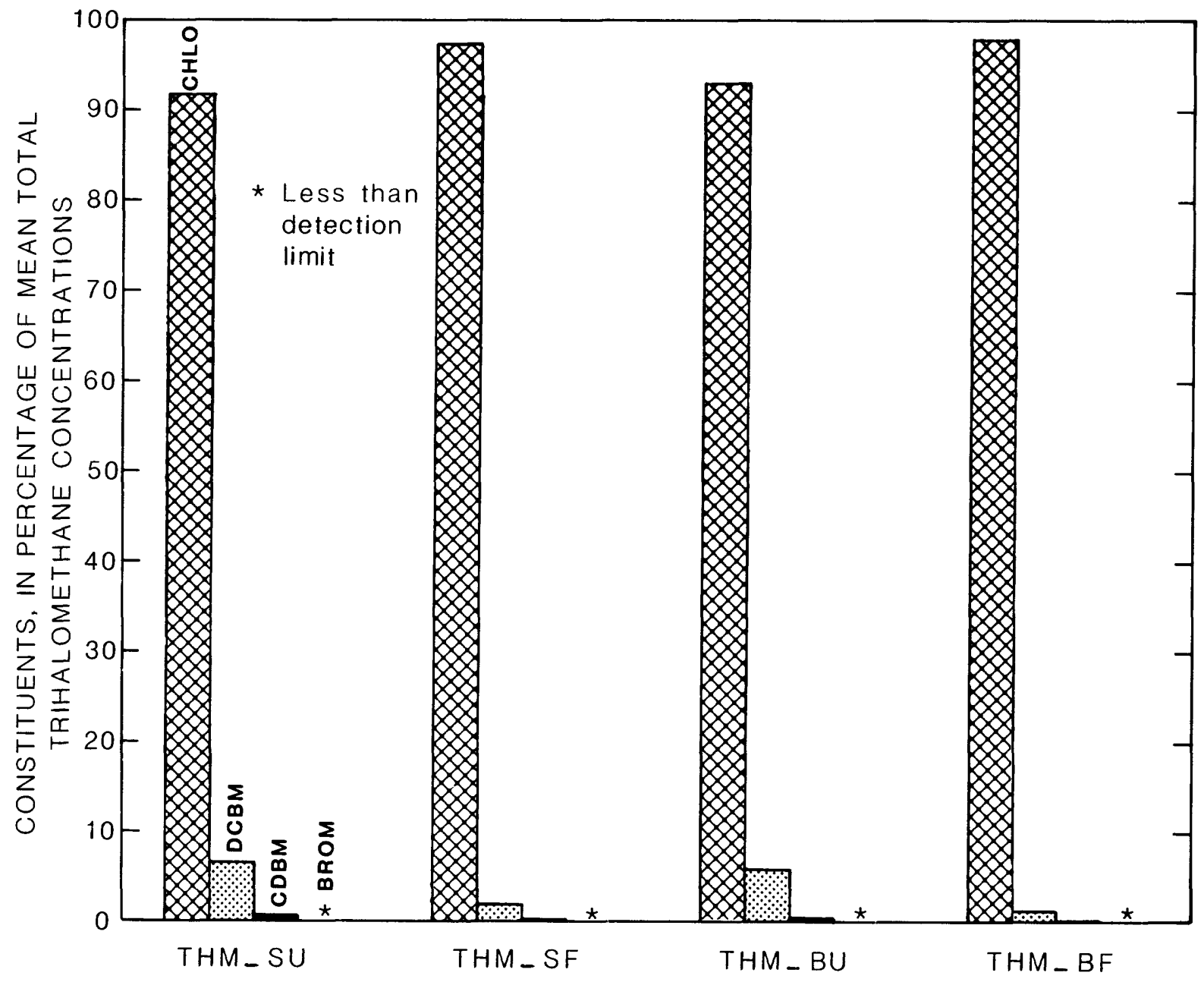

Figure 5. Percentages of chloroform (CHLO), dichlorobromomethane (DCBM), chlorodibromomethane (CDBM), and bromoform (BROM), in mean concentrations of total trihalomethanes formed during maximum trihalomethane-formation potential test in unfiltered surface water (THM_SU), filtered surface water (THM_SF), unfiltered bottom water (THM_BU), and filtered bottom water (THM_BF).

Mean concentrations of total THMs formed were larger in unfiltered samples than in filtered samples for both surface and bottom water (fig. 6). Specifically, mean concentrations of total THMs formed in unfiltered samples of surface and bottom water were 18 percent and 15 percent, respectively, larger than mean concentrations from filtered samples. Unfiltered samples contained TOC (DOC plus SOC) present in the source water at the time of sampling. Filtered samples contained only DOC present at the time of sampling because filtration removes SOC. Therefore, it might be concluded that SOC is directly responsible for an additional 16-percent (average) increase in total THM production relative to that produced in filtered samples. However, because it is generally recognized that THM formation is a
DOC-plus-chlorine reaction (see equation 1), what may have been occurring in the unfiltered samples was a decomposition of SOC to DOC during the 7-day incubation, with subsequent chlorination and production of additional THMs.

The decomposition of SOC (algal debris and leaf litter) may be microbial in nature or the result of cell lysis and subsequent leaching of soluble organic material. However, because chlorine acts as a biocide, it is believed, that after chlorination of test samples, biological decomposition of SOC would cease. Therefore, cell lysis and leaching probably are responsible for additional DOC formation and subsequent THM formation. Thurman (1985, p. 427) stated that leaching is virtually complete in 24 hours and may remove (convert SOC to DOC) 20 to 40 


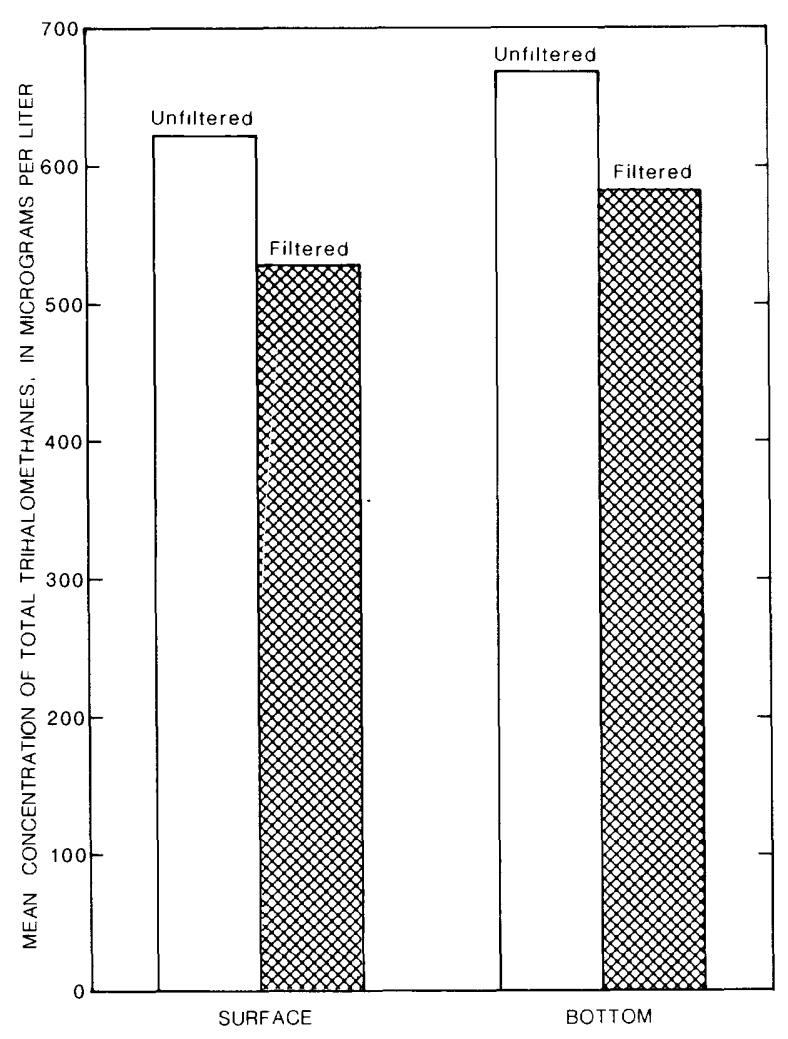

Figure 6. Comparison of mean concentrations of total trihalomethanes formed during maximum trihalomethane-formation potential test in unfiltered and filtered samples of surface and bottom water.

percent of the initial biomass. Using the mean concentrations for TOC and DOC in surface samples (table 6) and assuming the difference between the two $(1.51 \mathrm{mg} / \mathrm{L})$ represents SOC, then leaching of soluble organic material from SOC may provide (on the average) an additional 0.3 to $0.6 \mathrm{mg} / \mathrm{L}$ of $\mathrm{DOC}$ for potential chlorine reaction and, thus, a larger mean THM concentration in unfiltered samples.

Because no significant differences existed between mean concentrations of surface and bottom samples of TOC, DOC, THMs formed in unfiltered samples, and THMs formed in filtered samples, the data sets for surface and bottom chemical analyses were combined into one data set for analyses of frequency distributions. Frequency distributions of concentrations of TOC, DOC, and THMs for this combined data set are shown in figures 7 and 8 . These frequency distributions define the percentage of analyses that equaled or exceeded a selected concentration. For instance, figure 7 shows that, for TOC and DOC, 99 percent of observed concentrations equaled or exceeded 2.0 $\mathrm{mg} / \mathrm{L}$, but only 1 percent of the TOC concentrations equaled or exceeded $13.0 \mathrm{mg} / \mathrm{L}$, and only 1 percent of the DOC concentrations were greater than $7.0 \mathrm{mg} / \mathrm{L}$. In a similar manner, figure 8 indicates that 99 percent of total THM concentrations formed in unfiltered lake-water samples during the maximum formation-potential test exceeded $200 \mu \mathrm{g} / \mathrm{L}$, whereas 1 percent of those exceeded 1,500 $\mathrm{\mu g} / \mathrm{L}$. Equivalent percentages for total THMs formed in filtered water indicate THM concentrations of slightly less than $200 \mu \mathrm{g} / \mathrm{L}$ to about 1,200 $\mu \mathrm{g} / \mathrm{L}$.

The data in figure 7 also indicate one other interesting factor concerning TOC and DOC concentrations. Although a direct comparison between TOC and DOC concentrations cannot be made with this type of graph, it appears that TOC and DOC concentrations do not increase at equivalent rates, as indicated by the manner in which the frequency curves diverge at increasing concentrations. In other words, as TOC increases, DOC becomes a smaller percentage of TOC or, stated another way, SOC becomes a larger percentage of TOC with increasing TOC concentrations.

The SOC in Kansas water-supply lakes can be of either autochthonous or allochthonous origins. Natural or human-induced eutrophication (nutrient enrichment) may result in increased lake biomass. The increase in biomass will produce corresponding increases in DOC (cellular excretory products and lysis of algal cells) and SOC (photoplankton and zooplankton). Inflows from the watershed typically have large concentrations of SOC. In the more shallow lakes, this allochthonous SOC may be kept in suspension due to wind and wave action. In fact, the shallow lakes (Altamont West Lake, Osage City Reservoir, and Yates Center Reservoir, tables 16 and 17) have the largest TOC concentrations. In reality, however, concentrations of TOC in the study lakes are due to contributions of DOC and SOC from both autochthonous and allochthonous sources, and, with the data presently available, it is not possible to quantitatively assess the relative contribution of either source. 


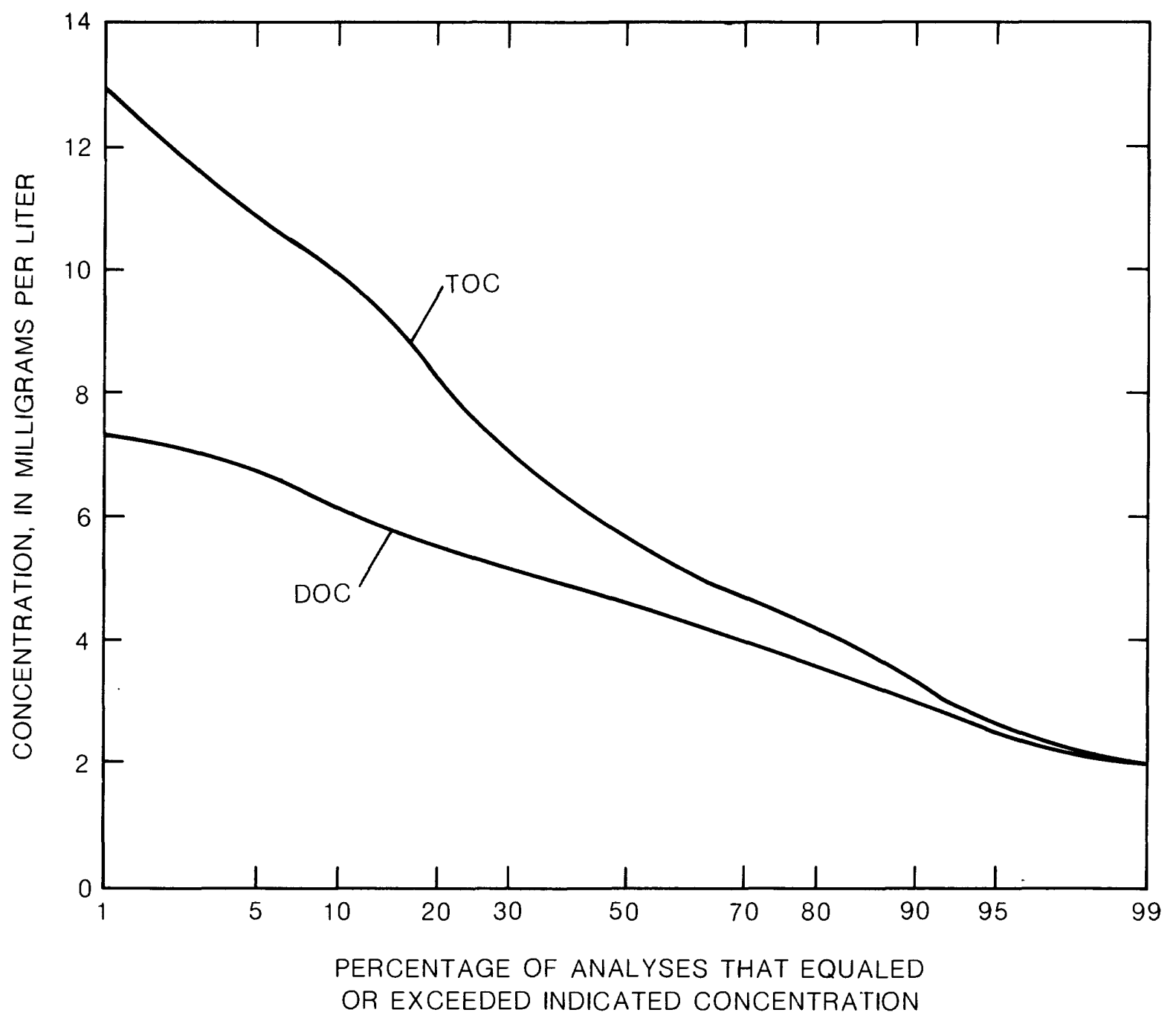

Figure 7. Frequency distribution of concentrations of total organic (TOC) carbon (DOC)and dissolved organic carbon in all study lakes.

RELATION OF TRIHALOMETHANEFORMATION POTENTIAL TO WATERQUALITY CHARACTERISTICS

The ability to predict trihalomethaneformation potential using water-quality characteristics of small lakes may provide lake managers an effective tool in evaluating the suitability of a particular water supply for public use both from a public-health and economic standpoint. Also, it may provide insight into existing THM-formation problems by defining possible causal relations between THM formation and specific water-quality characteristics. Subsequent corrective or preventive actions to limit the occurrence of a causal water-quality characteristic could provide a water-treatment operator with alternatives in water-treatment practices to decrease the potential for THM formation.

\section{Correlation Analysis}

As a preliminary step in defining potential relations between THM-formation potential and water-quality characteristics (table 7) a correlation analysis was conducted on mean values of selected water-quality characteristics for the 15 study lakes (table 8). Mean values were computed using all available data from analyses of lake-water samples collected at both the surface and near the bottom of each study lake. Pearson product-moment correlation coefficients and levels of significance were 


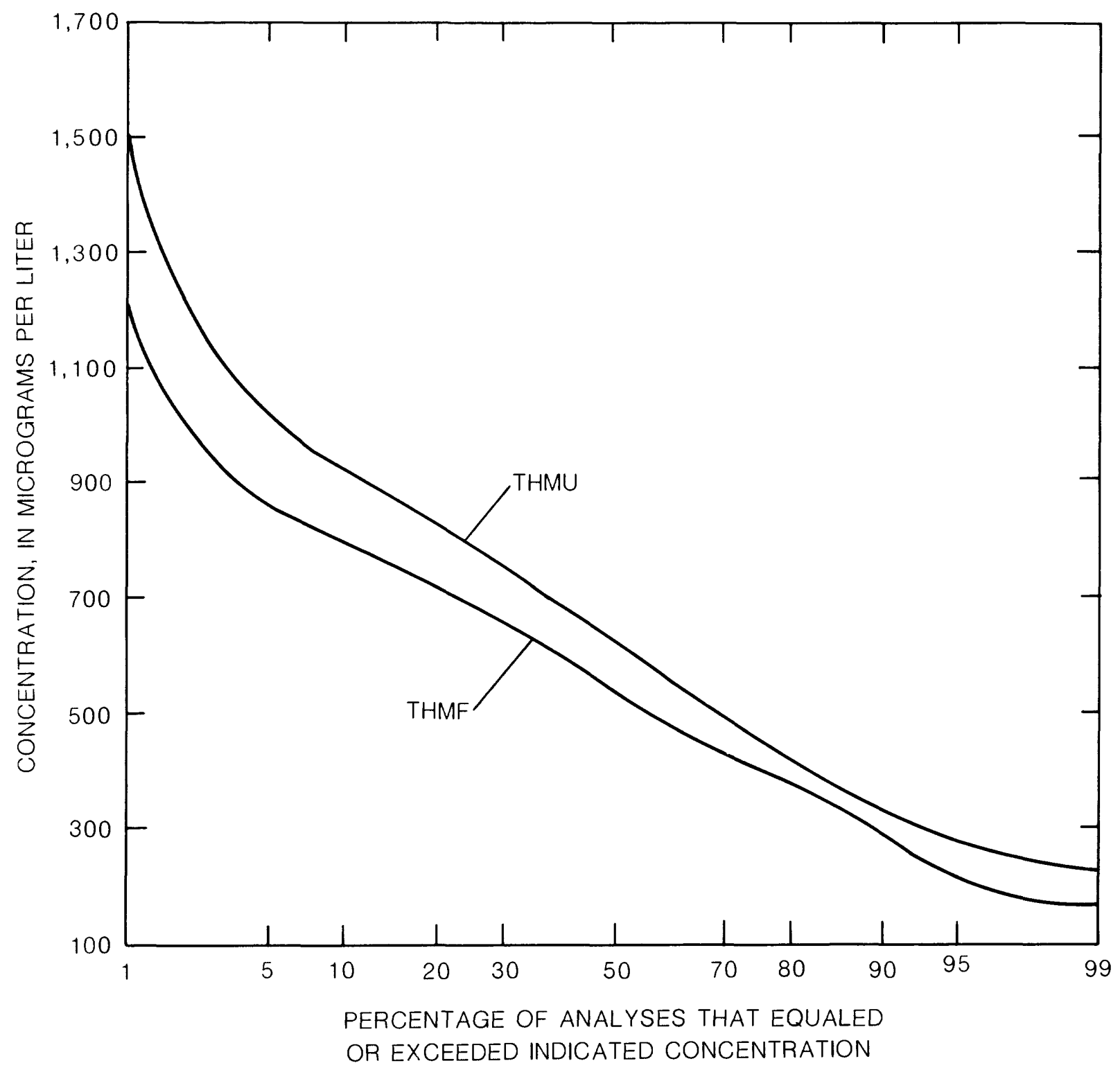

Figure 8. Frequency distribution of of concentrations of total trihalomethanes formed during maximum formation-potential test in unfiltered (THMU) and filtered (THMF) samples of water from all study lakes.

computed for all combinations of those characteristics listed in table 7 . Results of this correlation analysis are presented in table 9 .

Correlation analysis measures the degree of the linear relation between two variables and does not indicate causality. The correlation coefficient, an expression of the degree of the linear relation, ranges from -1.0 to 1.0. If all data points plot on a straight line and the relation is inverse or direct, the correlation coefficient will be -1.0 or 1.0 , respectively.
However, if the data points are randomly scattered, the correlation coefficient will be zero, and no linear relation exists. The larger the magnitude of the correlation coefficient, the better the fit (Blalock, 1972, p. 376-377).

An examination of table 9 indicates several significant relations between mean concentrations of THM-formation potential and other water-quality characteristics. In this report, a significant relation is defined as one in 
Table 7. Selected water-quality characteristics of water-supply lakes used in Pearson product-moment correlation analysis

[ $\mu \mathrm{g} / \mathrm{L}$, micrograms per liter; $\mathrm{mg} / \mathrm{L}$, milligrams per liter]

Water-quality characteristic $\begin{gathered}\text { Unit of Variable } \\ \text { measurement name }\end{gathered}$
1. Mean total trihalomethanes formed in unfiltered samples of lake water
2. Mean total trihalomethanes formed in filtered samples of lake water
3. Mean total organic carbon
4. Mean dissolved organic carbon
5. Mean total nitrite plus nitrate as nitrogen
6. Mean total ammonia as nitrogen
7. Mean total phosphorus
8. Mean dissolved oxygen
9. Mean chlorophyll-a

$\begin{aligned} \mu \mathrm{g} / \mathrm{L} & \text { MTHMU } \\ \text { do. } & \text { MTHMF } \\ \mathrm{mg} / \mathrm{L} & \text { MTOC } \\ \text { do. } & \text { MDOC } \\ \text { do. } & \text { MNO2N03 } \\ \text { do. } & \text { MNH4 } \\ \text { do. } & \text { MTP } \\ \text { do. } & \text { MDO } \\ \mu \mathrm{g} / \mathrm{L} & \text { MCHLA }\end{aligned}$

which its level of significance is at or better than 0.05 (numerically less than or equal to 0.05 ). The most significant relations (all at the 0.0001 level) occur between THM formation (MTHMU and MTHMF) and the organic constituents (MTOC and MDOC). The fact that THM formation is related to organic-carbon concentrations, of course, is not surprising because of the previously presented documentation that organic carbon (specifically DOC) contains the precursor material to THM formation. Somewhat unexpected, however, is the relation between THM formation in unfiltered lake water and total phosphorus $\mathbf{0 . 6 0}$ correlation coefficient). This relation probably exists because phosphorus can be a limiting nutrient in the production of algal biomass. For instance, large concentrations of phosphorus may induce algal proliferation, which in turn results in larger concentrations of organic carbon (note the 0.65 correlation coefficient between TOC and total phosphorus). These increased concentrations of organic carbon then can react with chlorine to produce larger concentrations of THMs than might be produced at smaller concentrations of phosphorus. Therefore, although phosphorus is not a direct causal characteristic (precursor material) to THM formation, it may serve, at least in a small way, as a predictor variable of THM-formation potential.

\section{Simple Linear-Regression Analysis}

Correlation analysis of THM-formation potential and other selected water-quality characteristics indicated that several significant relations exist between organic carbon and THM formation. To define these relations in a manner useful for estimation purposes, simple linear regression was used to relate mean concentrations of total and dissolved organic carbon to mean concentrations of THMs formed in unfiltered and filtered lake water. The results of this regression analysis are presented in figures 9 and 10 . The equations presented are of the form:

$$
Y=a+b x
$$

where $Y$ is the estimated mean concentration of THMs formed in unfiltered or filtered lake water, in micrograms per liter;

$a$ is the $y$-axis intercept value, a constant determined by the regression analysis;

b is the slope of the regression line, a constant determined by the regression analysis; and

$x$ is the independent variable, either mean concentration of TOC or DOC, in milligrams per liter.

All the relations presented in figures 9 and 10 are significant at the 0.0001 level and indicate that both mean concentrations of 


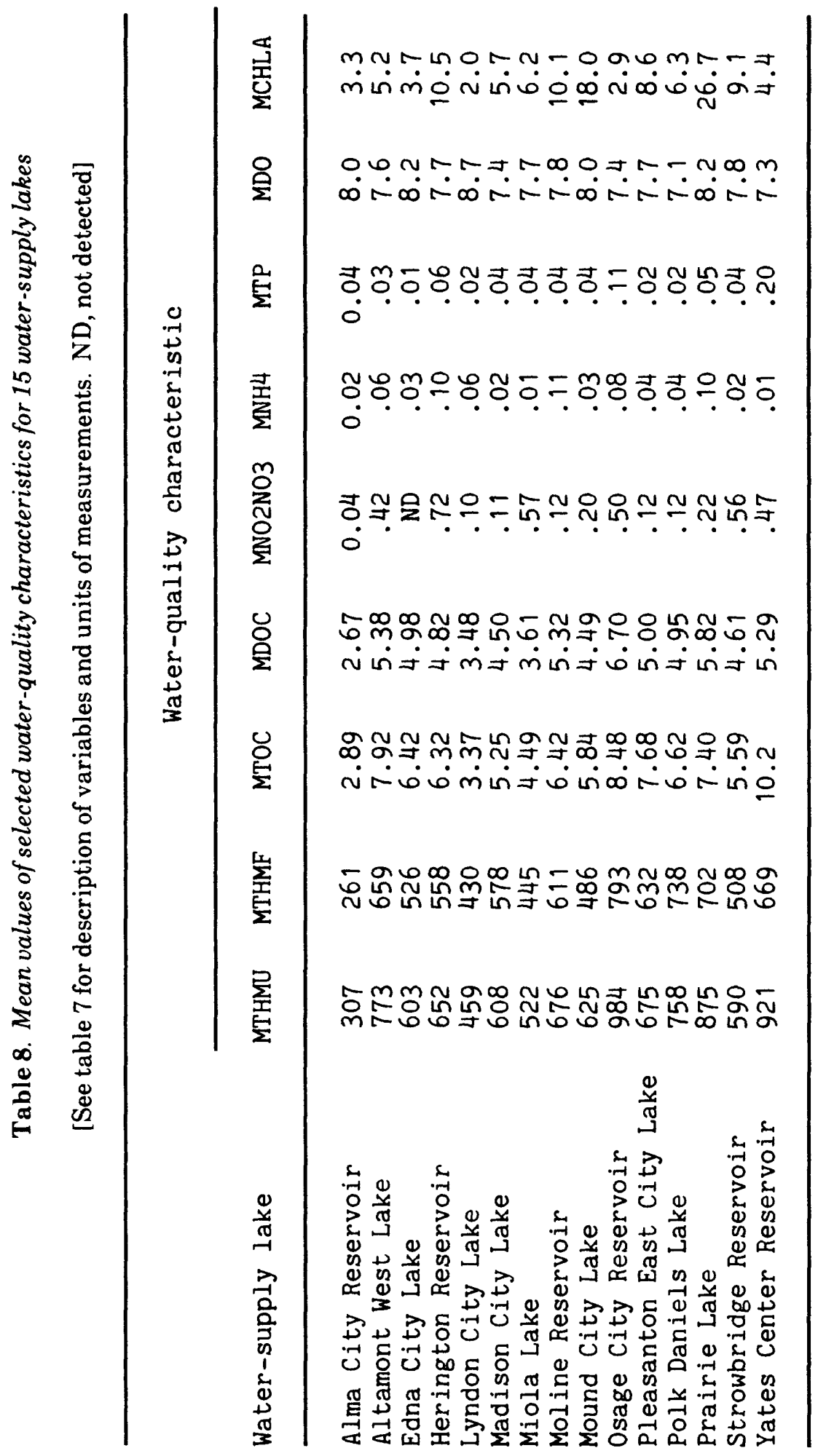


Table 9. Pearson product-moment correlation coefficients and levels of significance of selected water-quality characteristics for 15 water-supply lakes

[See table 7 for description of variables. LS, level of significance]

\begin{tabular}{|c|c|c|c|c|c|c|c|c|c|}
\hline & MTHMU & MTHMF & MTOC & MDOC & MNO2NO3 & MNH4 & MTP & MDO & MCHLA \\
\hline MCHLA & 0.25 & 0.19 & 0.14 & 0.27 & 0.03 & 0.43 & -0.08 & 0.22 & -- \\
\hline LS & .3746 & .5080 & .6144 & .3360 & .9284 & .1102 & .7819 & .4393 & \\
\hline MDO & -.50 & -.54 & -.54 & -.39 & -.38 & .13 & -.44 & -- & \\
\hline LS & .0581 & .0362 & .0388 & .1466 & .1671 & .6442 & .1015 & & \\
\hline MTP & .60 & .36 & .65 & .38 & .47 & -.05 & -- & & \\
\hline LS & .0183 & .1827 & .0091 & .1607 & .0780 & .8494 & & & \\
\hline MNH4 & .38 & .42 & .21 & .52 & .15 & -- & & & \\
\hline LS & .1625 & .1197 & .4632 & .0454 & .5944 & & & & \\
\hline MN02NO3 & .33 & .20 & .31 & .25 & -- & & & & \\
\hline LS & .2226 & .4644 & .2566 & .3653 & & & & & \\
\hline MDOC & .93 & .92 & .85 & -- & & & & & \\
\hline LS & .0001 & .0001 & .0001 & & & & & & \\
\hline MTOC & .92 & .86 & -- & & & & & & \\
\hline LS & .0001 & .0001 & & & & & & & \\
\hline MTHMF & .94 & -- & & & & & & & \\
\hline LS & .0001 & & & & & & & & \\
\hline MTHMU & -- & & & & & & & & \\
\hline
\end{tabular}

dissolved organic carbon (MDOC) and total organic carbon (MTOC) are good predictive variables of THM formation in unfiltered and filtered lake water. Correlation coefficients for the four relations range from 0.86 to 0.93 . The relation between MDOC and THM formation is not surprising because of previously presented information that indicated that THM formation is a reaction of chlorine and certain chemical functional groups naturally occurring in DOC. The fact that MTOC also is a significant predictor of THM formation is because DOC is the major component of TOC in the study lakes. On the average, DOC comprises 78 percent of the TOC in these lakes (table 8 , ratio of MDOC to MTOC expressed as a percentage). Further evidence of the DOC-TOC relation is indicated by the significant correlation $(0.85)$ between 

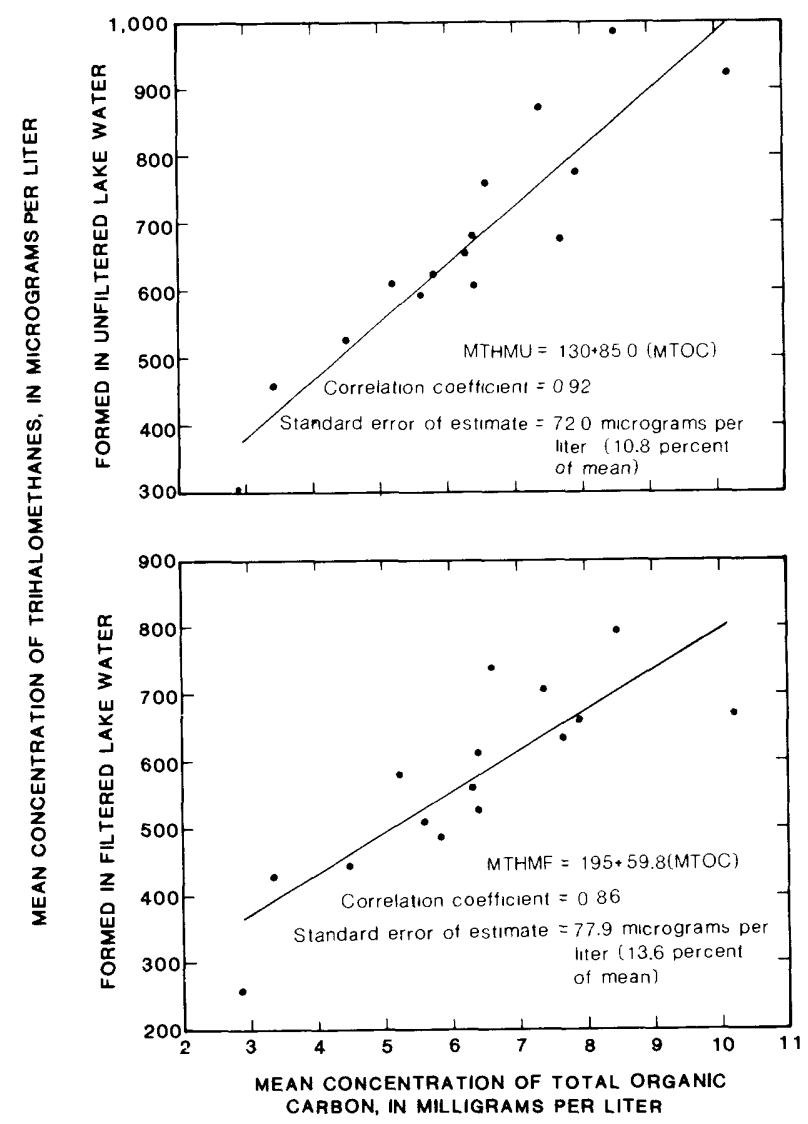

Figure 9. Relations between mean concentrations of trihalomethanes formed in unfiltered (MTHMU) and filtered (MTHMF) water and mean concentrations of total organic carbon (MTOC).

\section{MDOC and MTOC (table 9).}

An analysis of the residuals obtained from a regression procedure can indicate deficiencies in the regression models and whether the assumptions for ordinary least-squares (OLS) computations have been violated. Residuals are defined as the difference between the estimated and actual values of the dependent variable (the error of the model). Regression-model deficiencies or violation of OLS assumptions, which may be determined by an examination of residuals, include unequal residual variances (heteroscedasticity), inadequate model form, and clustered data. These deficiencies can be visualized by plotting the residuals against the predicted values of the dependent variable. When the plots were made, none of these nonlinear characteristics were observed with any of the equations shown in figures 9 and $\mathbf{1 0 .}$
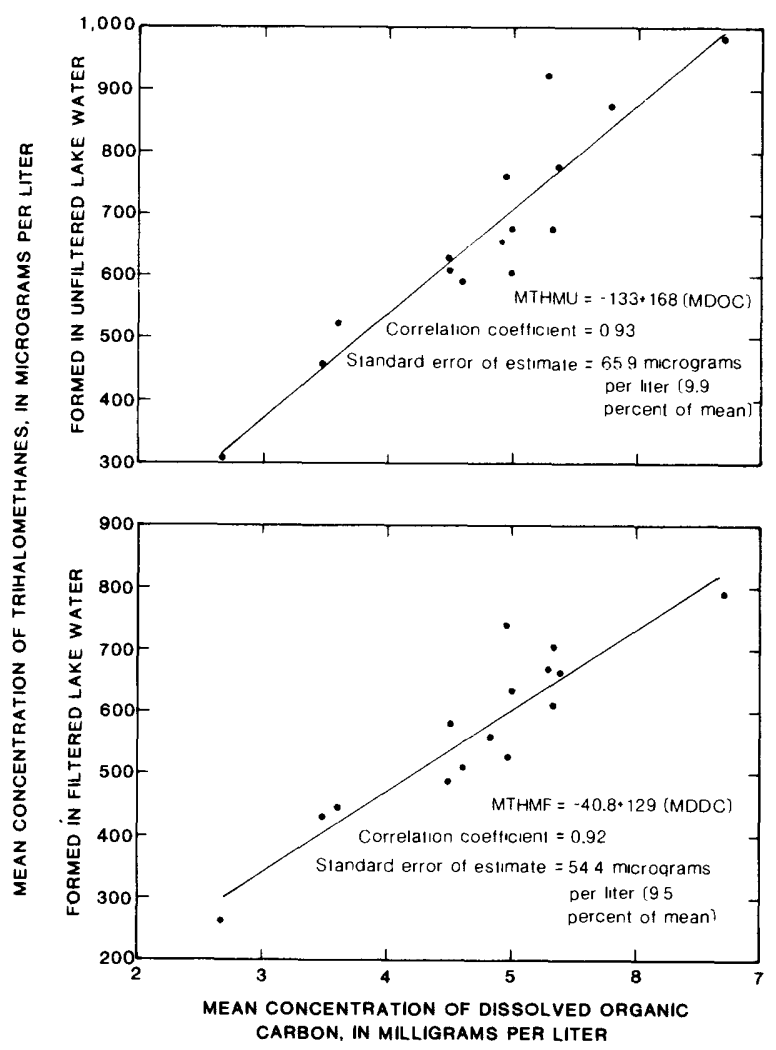

Figure 10. Relations between concentrations of trihalomethanes formed in unfiltered (MTHMU) and filtered (MTHMF) lake water and mean concentrations of dissolved organic carbon (MDOC).

Additionally, the Shapiro-Wilk test was performed on the residuals to determine if they were normally distributed, an assumption of the regression procedure. In all cases, the test indicated normality among the residuals. Therefore, it appears that the equations presented in figures 9 and 10 adequately fit the data and that they do not violate the OLS assumptions of the regression procedure.

In regard to the use of regression equations, the extrapolation of a regression equation beyond the range of the independent variable $(x)$ used in developing the regression equation is not appropriate for two reasons. First, as the difference between the mean value of the independent variable and the value used for estimation increases, the confidence intervals about the regression line become wider; second, the relation between the dependent and independent variables ( $\mathrm{Y}$ and $\mathrm{x}$ ) may be linear only within the range of $x$ investigated (Haan, 
1977, p. 192). Therefore, the equations in figures 9 and 10 are applicable only for lakes in which the mean concentrations of TOC or DOC are within the range of those investigated during this study (see table 8 ).

\section{Multiple-Regression Analysis}

Multiple-regression analysis was used to determine if estimates of potential for THM formation in small water-supply lakes could be improved with the addition of other waterquality characteristics to those equations presented in figures 9 and 10. Although these additional characteristics might not represent direct causal relations, they could be significant variables in the estimation of THM formation. The additional characteristics used as independent variables for this analysis are listed in table 7, items 5 to 9 . Values for these independent variables are listed in table 8.

\section{Method}

The equation used in the multiple-regression analysis is of the form:

$$
Y=a+b_{1} X_{1}+b_{2} X_{2}+\ldots b_{n} X_{n}
$$

where $\mathrm{Y}$ is the mean THM-formation potential concentration;

a is a constant determined by the regression analysis;

$b_{1-n}$ are regression coefficients determined by the regression analysis; and

$\mathrm{X}_{1-\mathrm{n}}$ are the mean values of waterquality characteristics used as independent variables.

In addition to the multiple-regression-analysis form presented in equation 3 , multipleregression analysis was used on logarithmictransformed data; however, the linear model in equation 3 provided as good or better a fit of the data than did the logarithmic models.

A stepwise procedure (Haan, 1977, p. 211) was used in the multiple-regression analysis. The stepwise procedure first selects the independent variable with the greatest simple correlation with the dependent variable. Additional independent variables are entered into the equation in order of the proportion of variation in the dependent variable that has not been explained by previously entered independent variables. After each entry step, an F-test for significance is conducted on the regression model and each independent variable. Those independent variables not determined to be significant (at least at the 0.05 level of significance) are deleted from the equation. This selection-deletion process continues until no independent variable can be determined that will be significant when entered into the equation. The stepwise procedure is considered to be an excellent method of developing a multiple-regression equation; however, care needs to be taken in evaluating the equation to insure that the independent variables are conceptually rational and statistically valid.

\section{Results}

Of the four simple linear-regression equations shown in figures 9 and 10 , only the relation between THM formation in unfiltered water (MTHMU) and MDOC produced significant improvement with the addition of other water-quality characteristics. A summary of the stepwise multiple-regression procedure relating MTHMU to additional water-quality characteristics is presented in table 10 . In addition to MDOC, mean concentration of total phosphorus (MTP) was determined to be significant in estimating MTHMU. The resultant multiple-regression equation is presented in table 11. The significance of MTP in estimating MTHMU has been discussed previously in the "Correlation Analysis" section of this report.

Examination of partial coefficients of determination ( $\left.\mathrm{R}^{2}\right)$ for a multiple-regression relation indicates the relative importance of each independent variable in explaining the variation of the dependent variable. In other words, the $R^{2}$ represents the proportion (percentage) of the variance of the dependent variable explained by the independent variable. For example, data in table 10 indicate that 87 percent of the variation of MTHMU is explained by MDOC alone. When MTP is added to the model, the only other independent variable 
significant at the 0.05 level, an additional 7 percent of the variation in MTHMU is explained. The remaining 6 percent of the variation is not explained by the model. Although MTP accounts for just 7 percent of the variation in MTHMU, the addition of it in the model does provide a 29-percent decrease in the standard error of estimate, a substantial improvement in model accuracy.

\section{RELATION OF TRIHALOMETHANE- FORMATION POTENTIAL TO PHYSICAL CHARACTERISTICS OF LAKES AND WATERSHEDS}

A knowledge of the relation between THM- formation potential in water from small watersupply lakes and physical characteristics of these lakes and watersheds could help to explain, predict, or alleviate the potential for THM formation during the water-treatment process. Definition of these relations could provide useful information when establishing design criteria of new water-supply lakes or when developing watershed-management practices to decrease the availability or development of precursor material of THM formation.

\section{Correlation and Simple Linear-Regression Analysis}

Correlation analysis was performed on mean

Table 10. Summary of stepwise multiple-regression procedure relating mean concentrations of trihalomethaneformation potential in unfiltered (MTHMU) lake water, in micrograms per liter, to mean concentrations of dissolved organic carbon (MDOC) and total phosphorus (MTP), in milligrams per liter, for 15 water-supply lakes

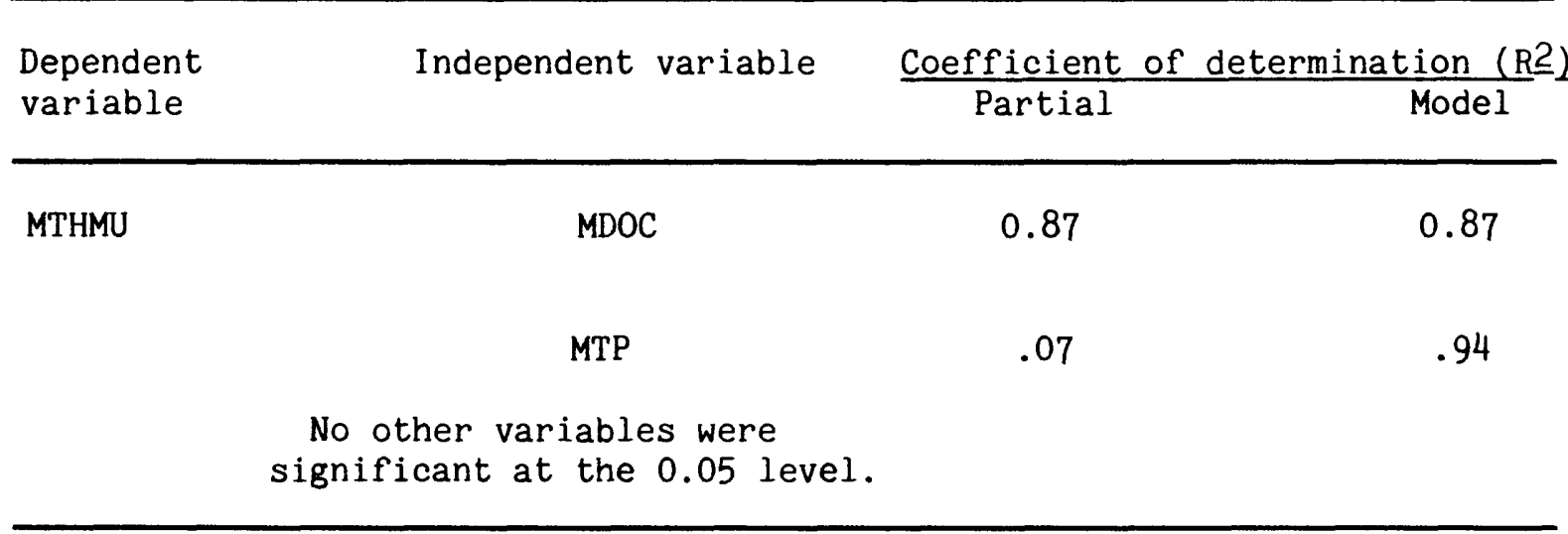

Table 11. Regression equation for estimating mean concentrations of trihalomethane-formation potential in unfiltered lake water (MTHMU), in micrograms per liter, from mean concentrations of dissolved organic carbon (MDOC) and total phosphorous (MTP) in 15 water-supply lakes

[Both the equation and independent variables are significant at the 0.0001 level. Independent variables are listed in order of decreasing significance, as calculated by an F-test]

Regression equation

Coefficient Standard error of estimate of determina- (micrograms (percent tion ( $\left.R^{2}\right) \quad$ per liter) of mean)
MTHMU
$=-9.40+148$
$(\mathrm{MDOC})+1,040(\mathrm{MTP})$
0.94
46.8
7.0 
Table 12. Selected water-quality characteristics and physical characteristics of lakes and watersheds used in Pearson product-moment correlation analysis

[ $\mu \mathrm{g} / \mathrm{L}$, micrograms per liter, mg/L, milligrams per liter, $\mathrm{ft}$, feet]

Water-quality or physical characteristic

Unit of

measurement
Variable

name

$\begin{array}{lll}\text { 1. Mean total trihalomethanes formed in unfiltered } & \mu g / L & \text { MTHMU } \\ \text { samples of lake water } & & \text { MTHMF } \\ \text { 2. Mean total trihalomethanes formed in filtered } & \text { do. } & \\ \text { samples of lake water } & \mathrm{mg} / \mathrm{L} & \text { MTOC } \\ \text { 3. Mean total organic carbon } & \text { do. } & \text { MDOC } \\ \text { 4. Mean dissolved organic carbon } & \text { years } & \text { AGE } \\ \text { 5. Age } & \text { acres } & \text { SA } \\ \text { 6. Surface area } & \text { do. } & \text { WA } \\ \text { 7. Watershed area } & \text { ratio } & \text { WSRAT } \\ \text { 8. Watershed area to lake-surface area } & \text { ft } & \text { MDEPTH } \\ \text { 9. Average maximum depth } & \text { percent } & \text { PCROP } \\ \text { 10. Watershed in protected cropland } & \text { do. } & \text { UCROP } \\ \text { 11. Watershed in unprotected cropland } & \text { do. } & \text { CROP } \\ \text { 12. Watershed in cropland (protected plus } & & \text { GGRASS } \\ \text { 13. Watershed in grazed grassland } & \text { do. } & \text { UGRASS } \\ \text { 14. Watershed in ungrazed grassland } & \text { do. } & \text { GRASS } \\ \text { 15. Watershed in grassland (grazed plus ungrazed) } & \text { do. } & \text { FOREST } \\ \text { 16. Watershed in forested land } & \text { do. } & \text { OTHER } \\ \text { 17. Watershed in other land use } & \text { do. }\end{array}$

concentrations of THM-formation potential, TOC, and DOC, and selected characteristics of lakes and watersheds. A list and description of these variables is presented in table 12 . Values for these variables have been presented previously in tables 2 and 8 . Pearson productmoment correlation coefficients and levels of significance were computed for all combinations of those variables listed in table 12. Results of this correlation analysis are presented in table 13.

Of the physical characteristics of lakes and watersheds listed in table 12 , items 5-17, only one has a significant relation to THM formation. As indicated in table 13, mean maximum depth (MDEPTH) has correlation coefficients of -0.80 and -0.77 with mean concentrations of THM formation in unfiltered (MTHMU) and filtered (MTHMF) lake water, respectively, both of which are significant at the 0.0008 level or greater. Additionally, and because of the significant relation between organic carbon and
THM formation, MTOC and MDOC also have a significant relation to MDEPTH. From a functional point of view, the relation between organic carbon and MDEPTH is the physical relation that ultimately controls THM formation because the precursor material for THM formation is organic carbon (specifically, a component of DOC).

Simple linear-regression analysis was performed on the relations between THM formation, organic carbon, and mean maximum depth of lake. The relations and results of the regression analysis are shown in figures 11 and 12. The results of the regression analysis include the regression equation, correlation coefficient (r), standard error of estimate (SEE), and level of significance (LS) of the relation. The regression equations are in the form presented in equation 2. Residuals for all four regressions presented in figures 11 and 12 were plotted against their respective dependent variable. No distinct patterns were observed 


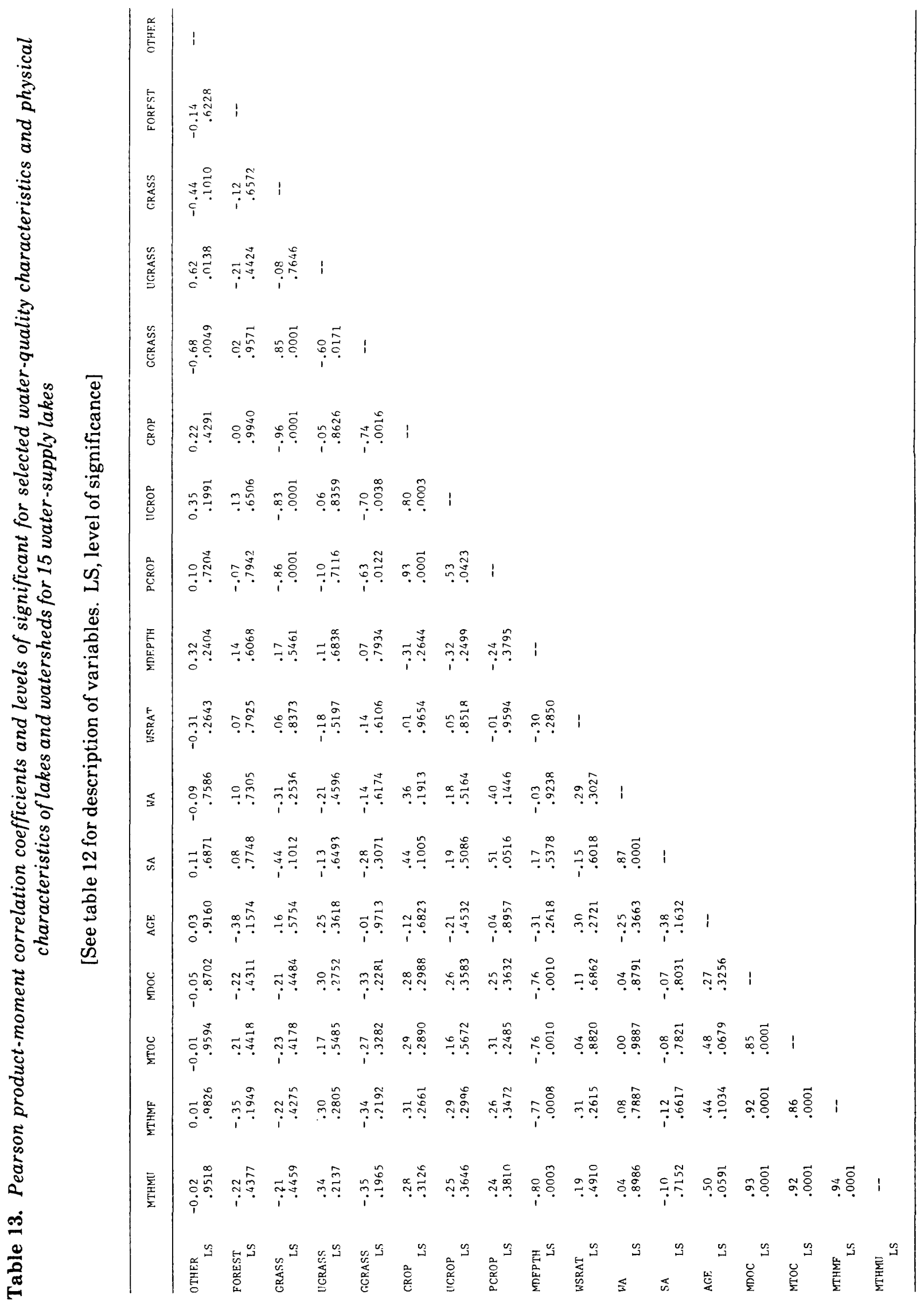




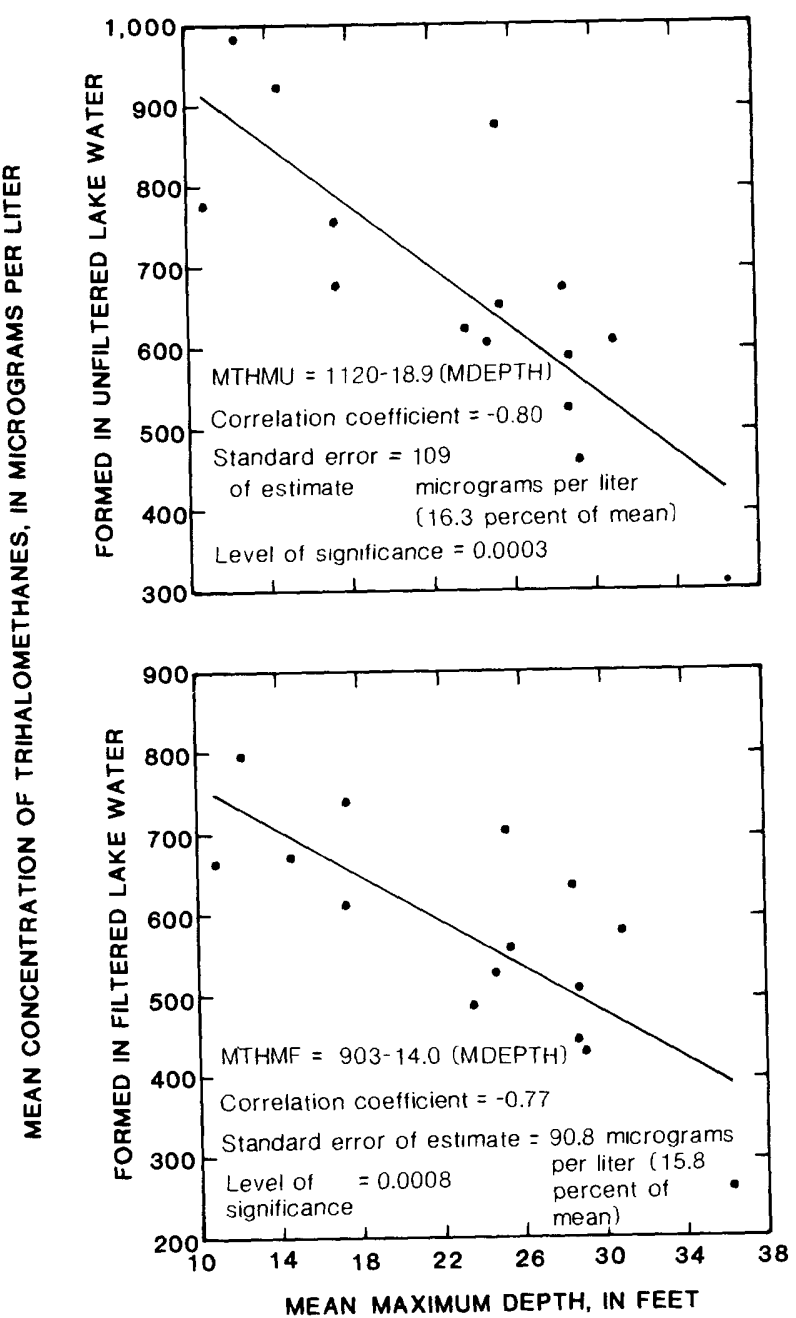

Figure 11. Relations between mean concentrations of trihalomethanes formed in unfiltered (MTHMU) and filtered (MTHMF) lake water and mean maximum depth of lake (MDEPTH).

with any of the residual plots. Also, the Shapiro-Wilk test verified a normal distribution among the residuals.

The inverse relations between THM formation and MDEPTH, and organic carbon and MDEPTH indicate that the deeper watersupply lakes studied in this investigation have a lesser potential for THM formation because of a smaller mean concentration of organic carbon, and vice versa. These inverse relations may be the result of one or a combination of several factors: (1) Deeper lakes may be less affected by

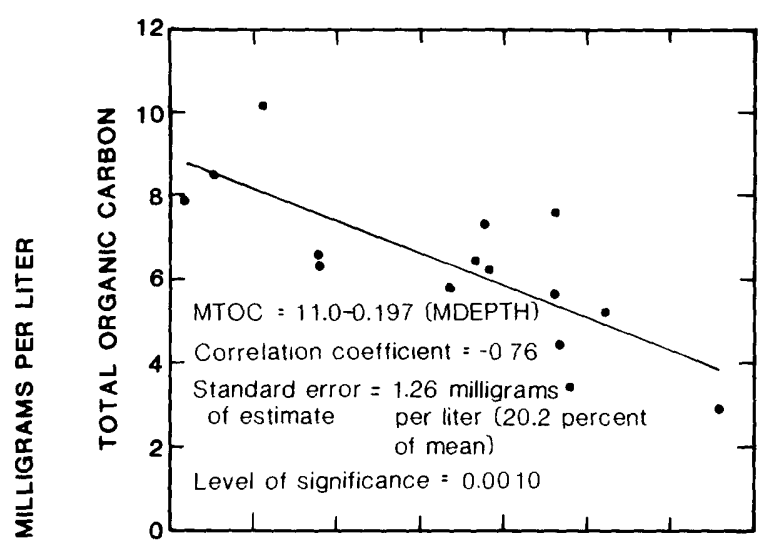

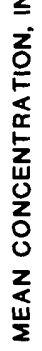

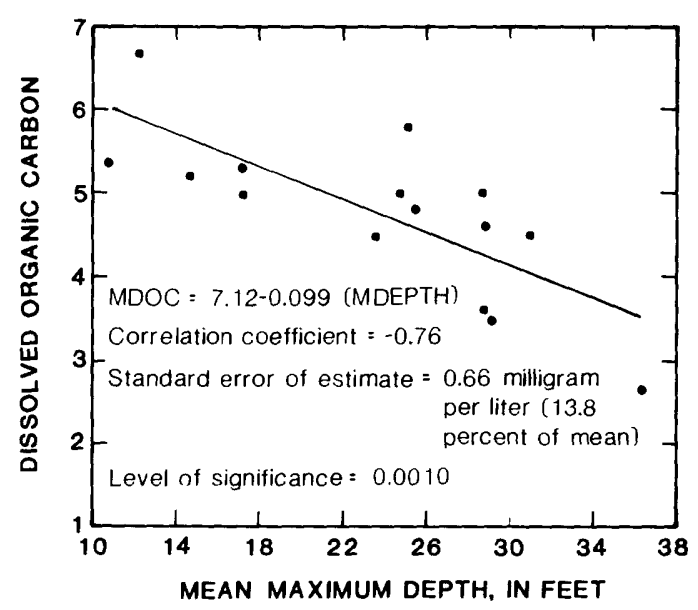

Figure 12. Relations between mean concentrations of total (MTOC) and dissolved (MDOC) organic carbon and mean maximum depth of lake (MDEPTH).

wind and wave action that, in shallow lakes, would tend to keep organic carbon in suspension rather than settling onto the bed sediments, as probably occurs in deeper lakes, and would tend to erode shoreline and introduce autochthonous organic matter into the lake; (2) deeper lakes may be less productive (generate less organic carbon) than shallow lakes because a smaller percentage of the volume of a deep lake will be within the photic zone (zone of photosynthetic activity); and (3) the deeper lakes in eastern Kansas are typically the larger lakes or are lakes formed in hilly topography which, in either case, would physically limit the extent or relative effect of the littoral zone, a shallow area characterized by the abundance of macrophytes (large aquatic plants consisting of flowering 
plants, ferns, mosses, liverworts, and large algae of the Charophyceae group). Macrophytes in some small, shallow lakes may be the dominant vegetation, constitute the largest biomass (Goldman and Horne, 1983, p. 139), and could, as a result of cellular excretion and decomposition, provide substantial quantities of organic carbon to the lake system.

\section{Multiple-Regression Analysis}

Simple linear regression has produced significant regression models to estimate THM formation and organic-carbon concentration from MDEPTH, the single most significant physical characteristic. In an attempt to improve the ability (explain more of the variation of the dependent variable) of these models to estimate water-quality characteristics, multiple-regression analysis was used to evaluate the significance of adding other physical characteristics (table 12, items 5 17) to the regression model. The stepwise procedure used for this multiple-regression analysis has been described previously.

A summary of the stepwise multipleregression procedure used to relate THM formation and concentrations of organic carbon to physical characteristics of lakes and watersheds is shown in table 14. In addition to MDEPTH, the only other physical characteristic that proved to be a significant (at the 0.05 level) variable in estimating these water-quality characteristics was percentage of watershed in ungrazed grassland (UGRASS). Of the three relations in which UGRASS was significant, it explained an additional 16 or 19 precent of the variation in the independent variable. Model coefficient-of-determination $\left(R^{2}\right)$ values ranged from 0.74 for MDOC to 0.84 for MTHMU. No physical characteristic other than MDEPTH was determined to be significant in estimating MTOC.

Regression equations developed from

Table 14. Summary of stepwise multiple-regression procedure relating mean concentrations of trihalomethaneformation potential in unfiltered (MTHMU) and filtered (MTHMF) lake water and total (MTOC) and dissolved (MDOC) organic carbon to physical characteristics of lakes and watersheds for 15 water-supply lakes

[Physical characteristics used as independent variables are described in table 12, items 5-17]

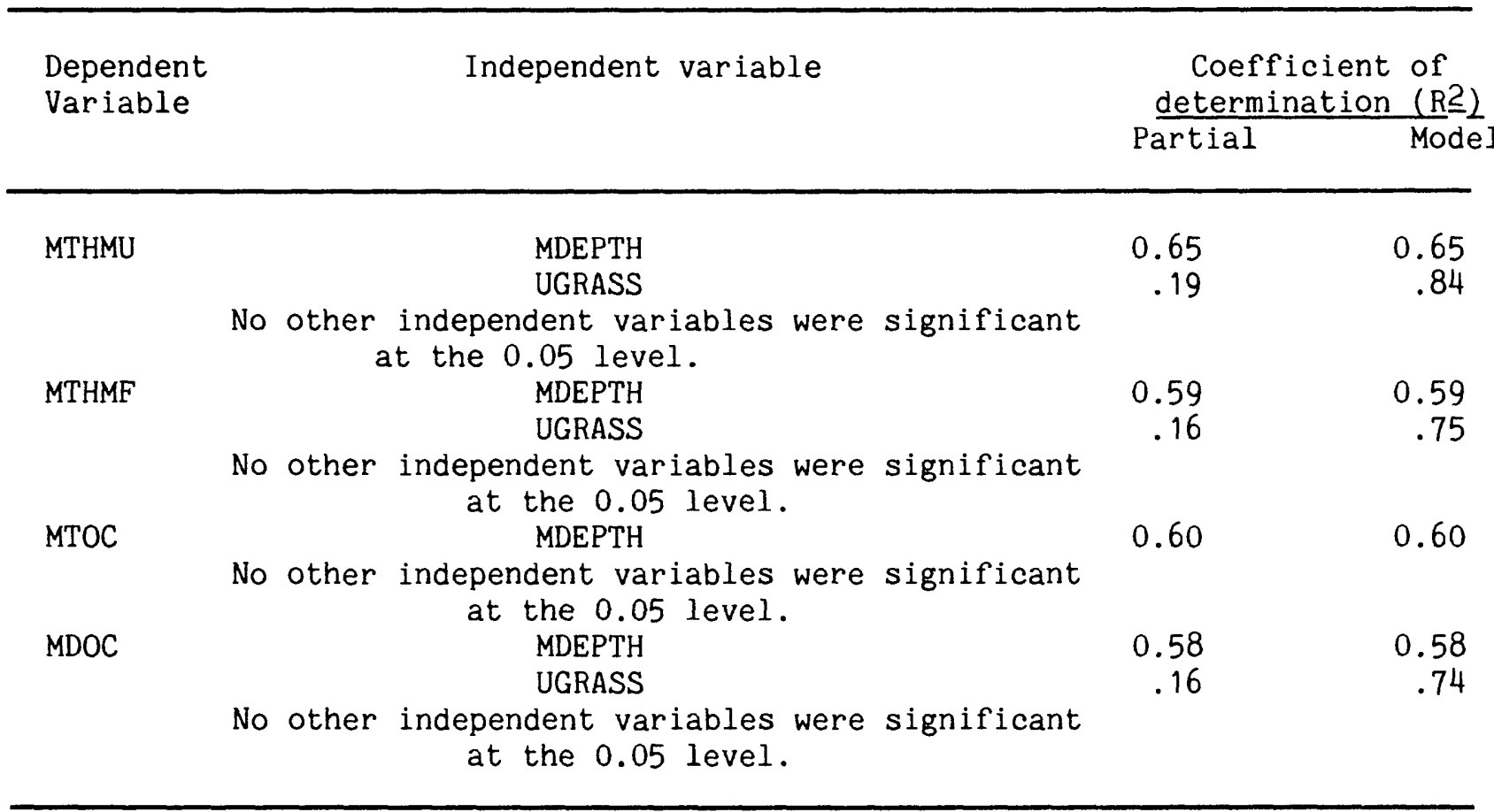




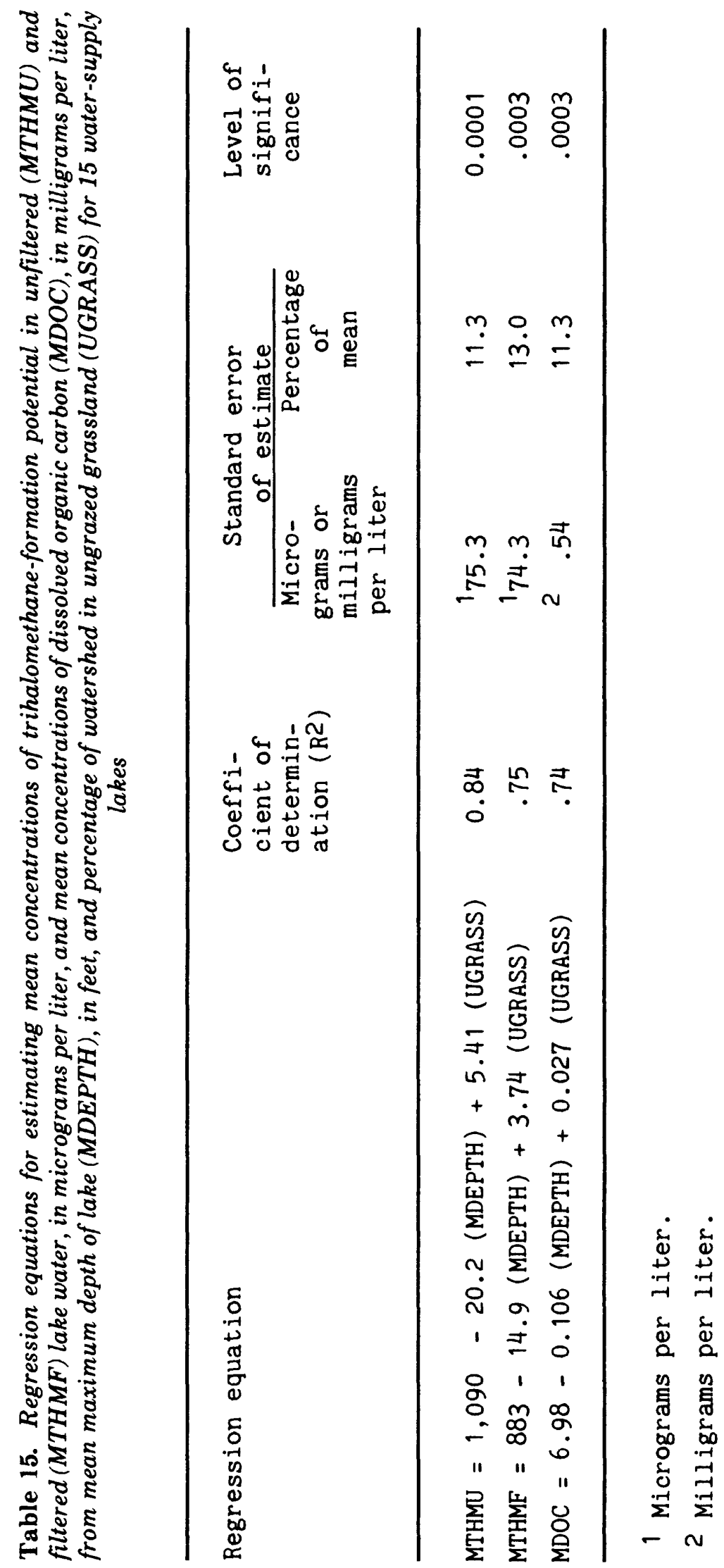


stepwise multiple-regression procedure for estimating mean concentrations of THMformation potential and TOC and DOC from physical characteristics of lakes and watersheds are shown in table 15. The equations indicate an inverse relation to MDEPTH and a direct relation to UGRASS. The relation to MDEPTH has been discussed previously in the "Correlation and Simple Linear-Regression Analysis" section of this report.

The significance of the direct relation of UGRASS in the multiple-regression equations for estimating MTHMU, MTHMF, and MDOC is due to one of three possibilities: (1) UGRASS is a significant contributor of DOC and resultant THM formation to small water-supply lakes and has a true causal relation; (2) UGRASS has no causal relation, but instead either is a predictive variable for DOC and THM formation or is a surrogate for some other undefined variable; or (3) UGRASS is neither causal nor predictive but appears in the equations merely by chance. It is believed that the latter of the three possibilities is the least likely given the level of significance $(0.0022$ to 0.0198$)$ of UGRASS in the three equations in which it appears. From an estimative perspective, it is of little importance whether the relation to UGRASS is causal (possibility 1) or predictive (possibility 2). However, from a watershedmanagement perspective, the distinction between possibility 1 and possibility 2 is of utmost importance.

A re-examination of the data in table 13 indicates some apparent inconsistencies among the three grassland variables and their relations to THM formation and organic-carbon concentrations. Although none of the individual relations are significant at any meaningful level of significance, the direction (direct or inverse) of the relations provides some useful information. The relations between THM formation and organic carbon are all direct for UGRASS but are all inverse for GGRASS (grazed grassland) and GRASS (grazed plus ungrazed grassland). A possible explanation for this difference in direction may be due to the inverse relation between UGRASS AND GGRASS (-0.60); as the percentage of UGRASS in a watershed increases, there is a corresponding decrease in GGRASS. Therefore, it may be expected that the relations between
THM formation and DOC with the two grassland categories would have opposite directions.

Perhaps the proper way of evaluating the contribution of grassland to THM formation and mean concentrations of organic carbon is to examine the relations between these dependent variables and the summation of ungrazed and grazed grassland (GRASS). In all four correlations with GRASS (table 13), the relations are inverse $(-0.21$ to -0.23$)$. Although these relations are not statistically significant, the direction of the relations gives support to the belief that grassland contributes less to loadings of allochthonous organic carbon than does cropland because of lesser biomass production and decreased rates of runoff and subsequent transport of organic material.

The assumption of lesser biomass production on grassland compared to cropland is supported in Odum (1967, p. 73) where biomass production from several ecosystems are compared. Annual net primary productivity for tall-grass prairies (Oklahoma and Nebraska) has been calculated at $446\left(\mathrm{~g} / \mathrm{m}^{2}\right) / \mathrm{yr}^{1}$ (grams per square meter per year). Annual net primary productivity for wheat ranged from $344\left(\mathrm{~g} / \mathrm{m}^{2}\right) / \mathrm{yr}$ as a world average to $1,250\left(\mathrm{~g} / \mathrm{m}^{2}\right) / \mathrm{yr}$ as an average in areas of largest yields. Corresponding values for oats were 359 to $926\left(\mathrm{~g} / \mathrm{m}^{2}\right) / \mathrm{yr}$ and those of corn were 412 to $790\left(\mathrm{~g} / \mathrm{m}^{2}\right) / \mathrm{yr}$. Given the use of fertilizers, pesticides, and normally adequate rainfall, productivity values for eastern Kansas should be similar to the average of largest yields for all grains, all of which, therefore, are significantly larger than the net productivity in grassland areas.

Although grains, which are a substantial part of the biomass of a cropland, are removed during harvest, the vegetative structures of the plants are left in the fields. In grassland areas, a major part of the net productivity is utilized by grazing animals (grazed grasslands) or is removed by haying operations (ungrazed grassland). Therefore, it is believed that even after harvest more biomass remains in cropland areas than in grassland areas.

$1\left(\mathrm{~g} / \mathrm{m}^{2}\right) / \mathrm{yr} \times 0.001838=\left(\mathrm{lbs} / \mathrm{yd}^{2}\right) / \mathrm{yr}$ (pounds per square yard per year). 
Given the contradictory nature of the grassland relations, evaluation of net primary productivity, and the fact that UGRASS represents such a small percentage (small variation) of watershed land use (table 2), it is believed that UGRASS, as a causal variable, should not be explaining 16 to 19 percent of the variation in MTHMU, MTHMF, and MDOC. Therefore, it is believed that UGRASS is only a predictive variable in estimating mean concentrations of THM-formation potential and DOC and does not represent a causal relation, at least not with the data presently available. Therefore, the multiple-regression equations that contain UGRASS (table 15) are appropriate only for estimative purposes and not for use as a watershed-management tool.

\section{SUMMARY}

The formation of carcinogenic trihalomethanes (chiefly chloroform, dichlorobromethane, chlorodibromomethane, and bromoform) during the disinfection of water supplies with chlorine has developed into a potentially serious problem. A knowledge of the formation potential of trihalomethanes in water from small water-supply lakes and its relation to water-quality characteristics and physical characteristics of lakes and watersheds would provide insight in evaluating current problems or decreasing the potential for future problems.

Fifteen small, public water-supply lakes, located in the 43-county eastern one-third of Kansas, were selected for this investigation. Data were collected from April 1984 through April 1986. These data consisted of measurements of specific conductance, $\mathrm{pH}$, water temperature, turbidity, transparency, and concentrations of dissolved oxygen, dissolved solids, nutrients, iron, manganese, total and dissolved organic carbon, chlorophyll$a$, and maximum trihalomethane-formation potential in both surface and bottom water. Data describing physical characteristics of lakes and watersheds also were collected.

A statistical analysis of trihalomethaneformation potential and mean concentrations of organic carbon produced several conclusions. Mean concentrations of total and dissolved organic carbon had no long-term statistically significant differences between surface- and bottom-water data sets for the 15 study lakes as a group. Based on mean concentrations of trihalomethanes formed during the U.S. Environmental Protection Agency's maximum formation-potential test, chloroform was the predominant trihalomethane species. Chloroform averaged 95 percent of the mean concentration of trihalomethanes formed in all four test categories (unfiltered surface water, filtered surface water, unfiltered bottom water, and filtered bottom water). Dichlorobromomethane averaged 4.3 percent, and chlorodibromomethane averaged 0.4 percent of the mean concentrations of trihalomethanes formed in the four test categories. No bromoform was detected. As was determined with total and dissolved organic carbon, no longterm, statistically significant differences were determined between mean concentrations of trihalomethanes formed in surface- and bottomcollected water for the $\mathbf{1 5}$ study lakes as a group. However, mean concentrations of trihalomethanes formed in unfiltered lake water were significantly larger than those formed in filtered lake water.

Relations of trihalomethane-formation potential to selected water-quality characteristics were investigated using correlation and simple linear-regression analysis. Significant relations $(0.05$ level of significance or better) were produced between mean concentrations of trihalomethaneformation potential and total and dissolved organic carbon (the source of precursor material to trihalomethane formation). Correlation coefficients for relations between mean concentrations of trihalomethanes formed in unfiltered and filtered lake water (dependent variables) and mean concentrations of total organic carbon (independent variable) were 0.92 and 0.86 , respectively, with standard errors of estimate equal to 10.8 and 13.6 percent of the mean of the dependent variable. Corresponding trihalomethane relations to dissolved organic carbon (independent variable) were 0.93 and 0.92 , respectively, with standard errors of estimate equal to 9.9 and 9.5 percent of the mean of the dependent variable.

Stepwise multiple-regression analysis was used to relate a combination of water-quality characteristics to mean concentrations of trihalomethane-formation potential; however, 
only one relation resulted in significant improvement with the addition of other waterquality characteristics. The equation for estimating mean concentration of trihalomethane formed in unfiltered lake water from mean concentrations of dissolved organic carbon had a significant improvement with the addition of mean concentration of total phosphorus. The coefficient of determination (square of the correlation coefficient) improved from 0.87 to 0.94 , and the standard error of estimate was decreased to 7.0 percent of the mean of the dependent variable.

Relations between trihalomethaneformation potential and organic carbon and selected physical characteristics of lakes and watersheds were investigated using correlation and simple linear-regression analysis. Significant relations were produced between mean concentrations of trihalomethaneformation potential and organic carbon, and mean maximum depth of lake. Correlation coefficients for relations between mean concentrations of trihalomethanes formed in unfiltered and filtered lake water (dependent variables) and mean maximum depth of lake (independent variable) were -0.80 and -0.77 , respectively, with standard errors of estimate equal to 16.3 and 15.8 percent of the mean of the dependent variable. Correlation coefficients for relations between mean concentrations of total and dissolved organic carbon (dependent variables), and mean maximum depth of lake (independent variable) were -0.76 and -0.76 , respectively, with standard errors of estimate equal to 20.2 and 13.8 percent of the dependent mean. Mean maximum depth of lake was the only physical characteristic that produced significant relations to mean concentrations of trihalomethane-formation potential or organic carbon.

Stepwise multiple-regression analysis was used to determine if combinations of physical characteristics might improve the estimative power of the simple linear-regression equations. Percentage of watershed in ungrazed grassland was the only other physical characteristic to have significance in estimating mean concentrations of trihalomethane-formation potential and dissolved organic carbon. However, it is believed that percentage of ungrazed grassland, with the data presently available, does not represent a true causal relation to either mean concentrations of trihalomethane-formation potential or dissolved organic carbon, but merely is a predictive variable or is a surrogate for some other undefined variable. Use of percentage of ungrazed grassland in the multiple-regression equations, therefore, needs to be restricted to estimative purposes; its use as a watershedmanagement tool is not appropriate.

\section{REFERENCES CITED}

American Public Health Association, 1975, Standard methods for the examination of water and wastewater (14th ed.): Washington, D.C., 1142 p.

Bellar, T.A., Lichtenberg, J.J., Brass, H.J., Stevens, A.A., and Moore, L.A., 1982, The determination of the maximum total trihalomethane formation potential, method 510.1: U.S. Environmental Protection Agency report, EPA 600/4-81-044, unnumbered pages.

Blalock, H.M., Jr., 1972, Social statistics: New York, McGraw-Hill Co., $496 \mathrm{p}$.

Boyce, S.D., and Hornig, J.F., 1983, Reaction pathways of trihalomethane formation from the halogenation of dihydroxyaromatic model compounds for humic acid: Environmental Science and Technology, v. 17 , no. 4, p. 202-211.

Carswell, W.J., Jr., 1982, Storage requirements to sustain gross reservoir outflow from small basins in Kansas: Kansas Water Office Technical Report 16, p. 28-29.

Catruvo, J.A., 1981, THM's in drinking water: Environmental Science and Technology, v. 15 , no. 3 , p. $268-274$.

Cumming, R.B., 1978, Metagenicity and water chlorination--Prospect and perspective, in Jolley, R.L., and others, eds., Water chlorination--Environmental input and health effects: Ann Arbor, Mich., Ann Arbor Science Publishers,v. 12, p. 411-416. 
Goldman, C.R., and Horne, A.J., 1983,

Limnology: New York, McGraw-Hill Co., $139 \mathrm{p}$.

Greeson, P.E., Ehlke, T.A., Irwin, G.A., Lium, B.W., and Slack, K.V., eds., 1977, Methods for collection and analysis of aquatic biological and microbiological samples: U.S. Geological Survey Techniques of WaterResources Investigations, Book 5, Chapter A4, 332 p.

Haan, C.T., 1977, Statistical methods in hydrology: Ames, Iowa State University Press, $547 \mathrm{p}$.

Hoehn, R.C., Barnes, D.B., Thompson, C., Randall, W., and Grizzard, T.J., 1980, Algae as sources of trihalomethane precursors: Journal of American Water Works Association, v. 72 , no. 6 , p. 344-350.

Kenny, J.F., 1986, Water demands in Kansas, 1944-84: U.S. Geological Survey WaterResources Investigations Report 86-4038, 17 p.

Klugh, H.E., 1970, Statistics--The essentials for research: New York, John Wiley and Sons, $368 \mathrm{p}$.

Morris, J.C., and Baum, B., 1978, Precursors and mechanisms of haloform formation in the chlorination of water supplies, in Jolley, R.L., and others, eds., Water chlorination-Environmental impact and health effects: Ann Arbor, Mich., Ann Arbor Science Publishers, v. 2, p. 29-48.

Noack, M.G., and Doerr, R.L., 1978, Reactions of chlorine, chlorine dioxide, and mixtures thereof with humic acid--An interim report, in Jolley, R.L., and others, eds., Water chlorination--Environmental impact and health effects: Ann Arbor, Mich., Ann Arbor Science Publishers, v. 2, p. 49-58.

Norwood, D.L., Johnson, J.D., Christman, R.F., Hass, J.R., and Bobenrieth, M.J., 1980, Reactions of chlorine with selected aromatic models of aquatic humic material: Environmental Science and Technology, v. 14 , no. 2, p. 187-190.
O'Brien, D.J., Bixby, R.L., Jewett, M.A., and Stewart, K.M., 1980, Formation and control of trihalomethanes in chlorinated drinking waters containing fulvic acid: Durham, University of New Hampshire, Water Resource Research Center Research Report $27,82 \mathrm{p}$.

Odum, E.P., 1967, Fundamentals of ecology: Philadelphia, W.B. Saunders Co., 546 p.

Oliver, B.G., and Thurman, E.M., 1983, Influence of aquatic humic substance properties on trihalomethane potential, in Jolley, R.L., and others, eds., Water chlorination--Environmental impact and health effects: Ann Arbor, Mich., Ann Arbor Science Publishers, v. 4, p. 231-241.

Peters, C.J., Young, R.L., and Perry, R., 1980, Factors influencing the formation of haloforms in chlorination of humic materials: Environmental Science and Technology, v. 14, no. 11, p. 1391-1395.

Pope, L.M., Arruda, J.A., and Vahsholtz, A.E., 1985, Water-quality reconnaissance of selected water-supply lakes in eastern Kansas: U.S. Geological Survey WaterResources Investigation Report 85-4058, 47 p.

Reid, G.K., and Wood, R.D., 1976, Ecology of inland waters and estuaries: New York, D. Van Nostrand Co., 485 p.

Rook, J.J., 1974, Formation of haloforms during chlorination of natural waters: Journal of Water Treatment Examiner, no. 22, p. 234.

1977, Chlorination reactions of fulvic acids in natural waters: Environmental Science and Technology, v. 11, no. 5, p. 478-482.

Schneiderman, M., 1978, Risk assessment of the health effects of water chlorination, in Jolley, R.L., and others, eds., Water chlorination--Environmental impact and health effects: Ann Arbor, Mich., Ann Arbor Science Publishers, v. 2, p. 509-515. 
Schoewe, W.H., 1949, The geography of Kansas, part II--Physical geography: Transactions of the Kansas Academy of Science, v. 52, no. 3, p. 280-289.

Simmon, V.F., and Tardiff, R.G., 1978, The mutagenic activity of halogenated compounds found in the chlorinated drinking water, in Jolley, R.L., and others, eds., Water chlorination--Environmental impact and health effects: Ann Arbor, Mich., Ann Arbor Science Publishers, v. 2, p. 417-431.

Singer, P.C., Barry, J.J., Palen, G.M., and Scrivner, A.E., 1981, Trihalomethane formation in North Carolina drinking waters: Journal of the American Water Works Association, v. 73, no. 8, p. 392-401.

Skougstad, M.J., Fishman, M.J., Friedman, L.C., Erdman, D.E., and Duncan, S.S., eds., 1979, Methods for determination of inorganic substances in water and fluvial sediments: U.S. Geological Survey Techniques of Water-Resources Investigations, Book 5, Chapter A1, $626 \mathrm{p}$.
Stevens, A.A., and Symons, J.M., 1977, Measurement of trihalomethane and precursor concentration changes: Journal of the American Water Works Association, v. 69 , no. 10 , p. $546-554$.

Thurman, E.M., 1985, Organic geochemistry of natural waters: Dordrecht, Netherlands, Mantinus Nijhoff/Dr. W. Junk Publishers, $497 \mathrm{p}$.

U.S. Environmental Protection Agency, 1979a, Methods for chemical analysis of water and waste: U.S. Environmental Protection Agency report, EPA-600/4-79-200, unnumbered pages.

1979b, Purgeables--Method 624: Federal Register, v. 44, no. 233, p. 69532.

Wershaw, R.L., Fishman, M.J., Grabbe, R.R., and Lowe, L.E., eds., 1983, Methods for the determination of organic substances in water and fluvial sediments: U.S. Geological Survey Open-File Report 82$1004,173 \mathrm{p}$. 
SUPPLEMENTAL INFORMATION 


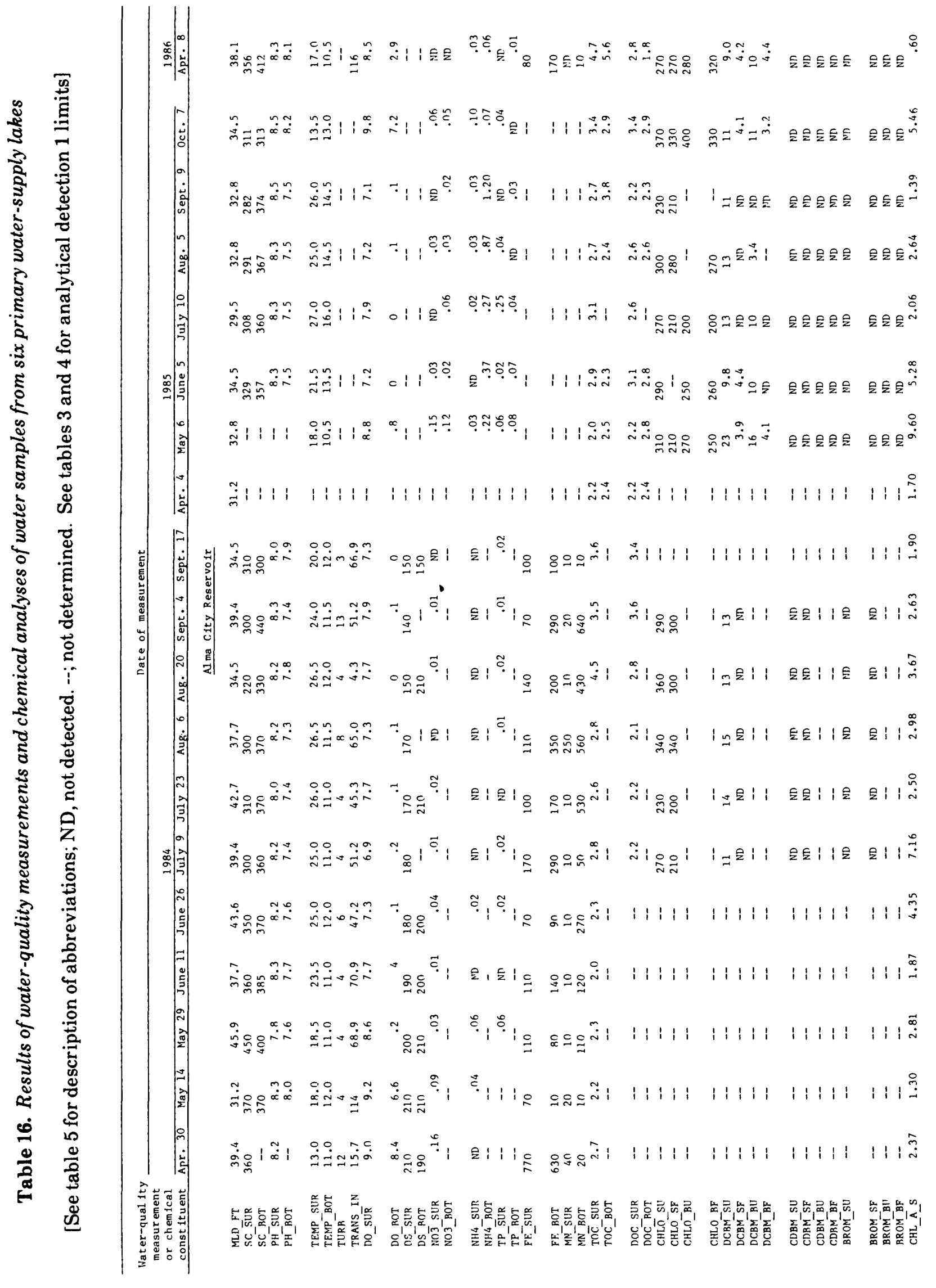




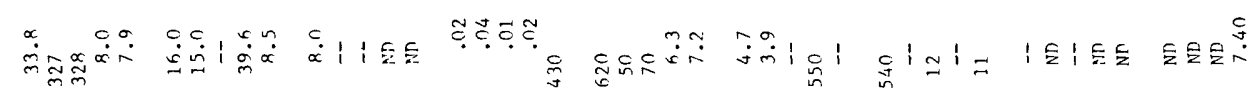

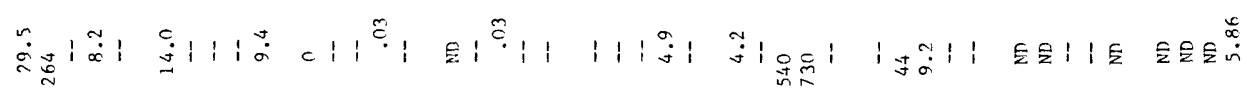

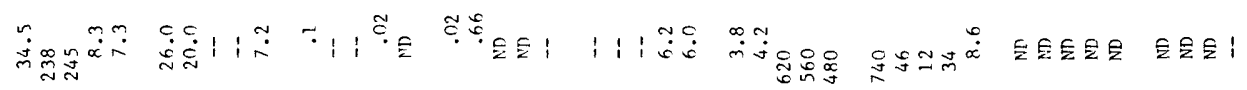

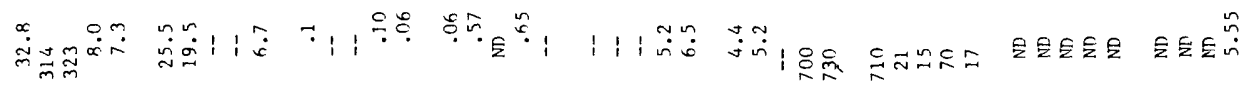

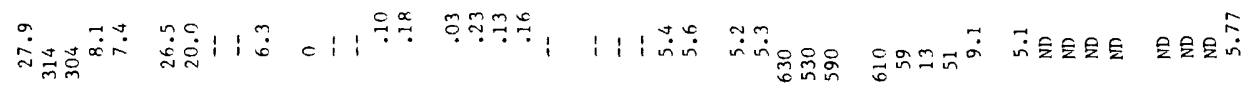

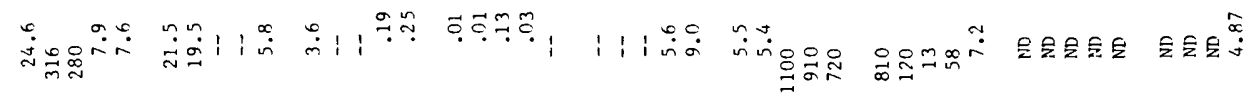
然111:

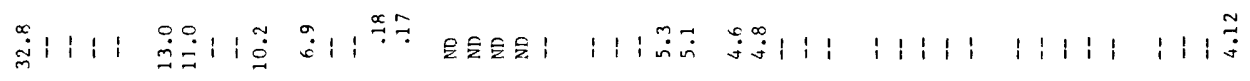

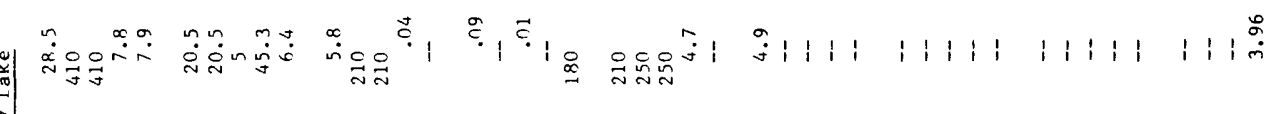

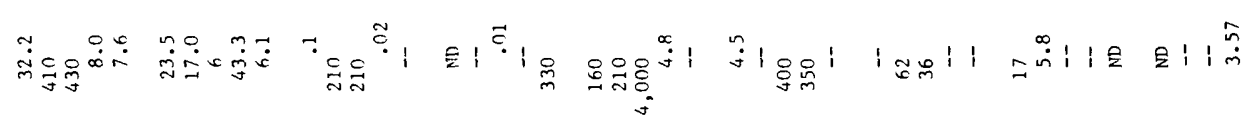

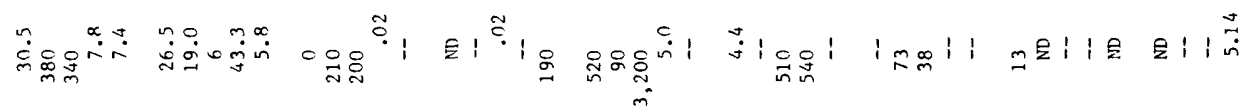

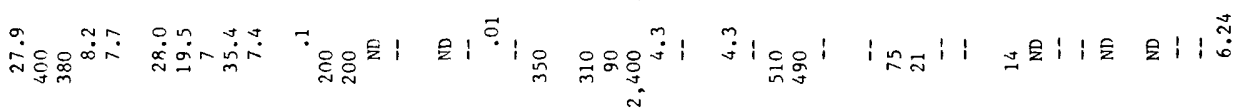

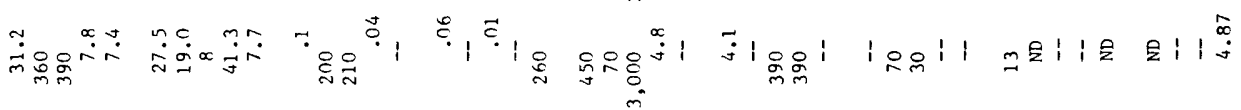

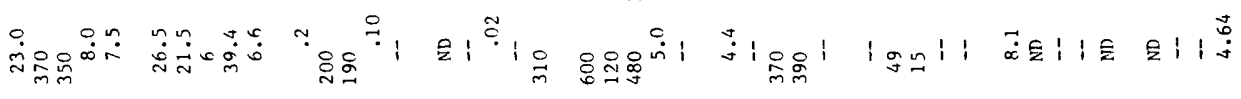

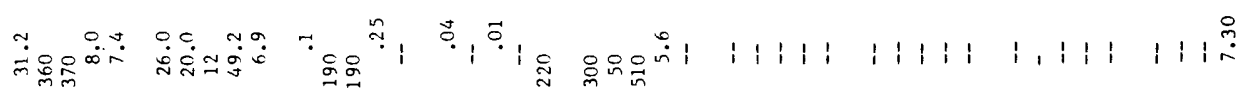

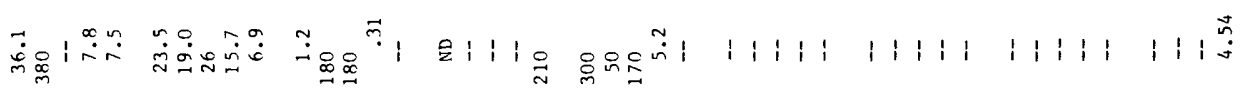

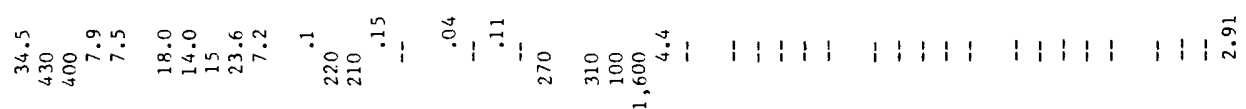

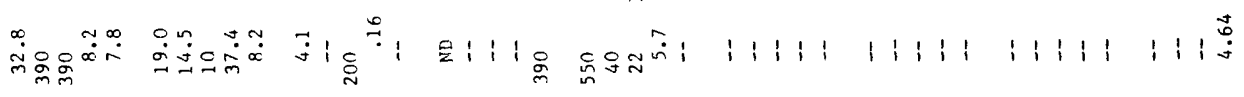

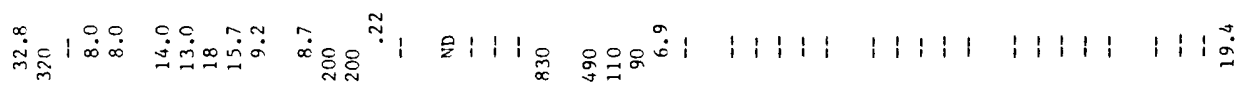




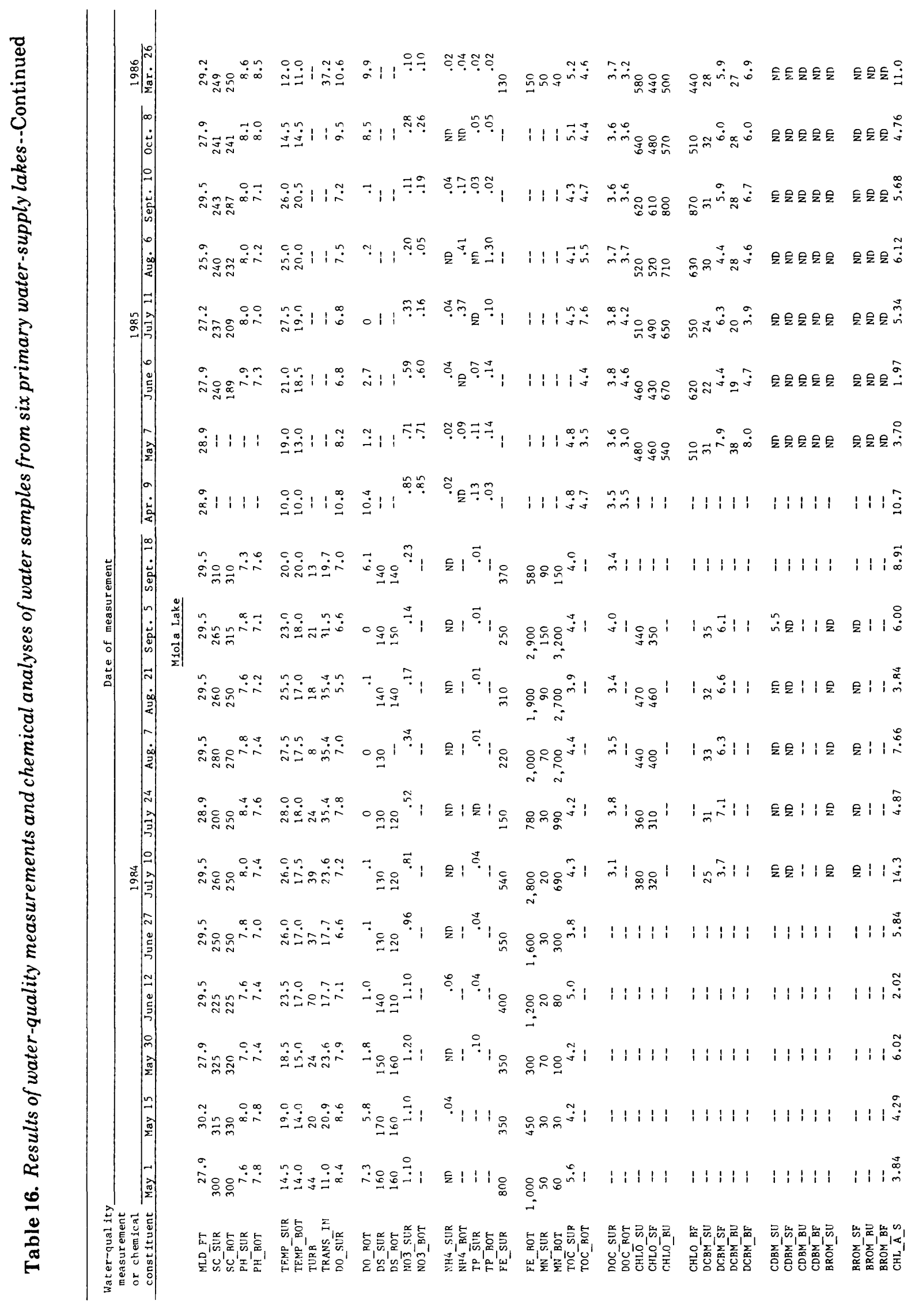




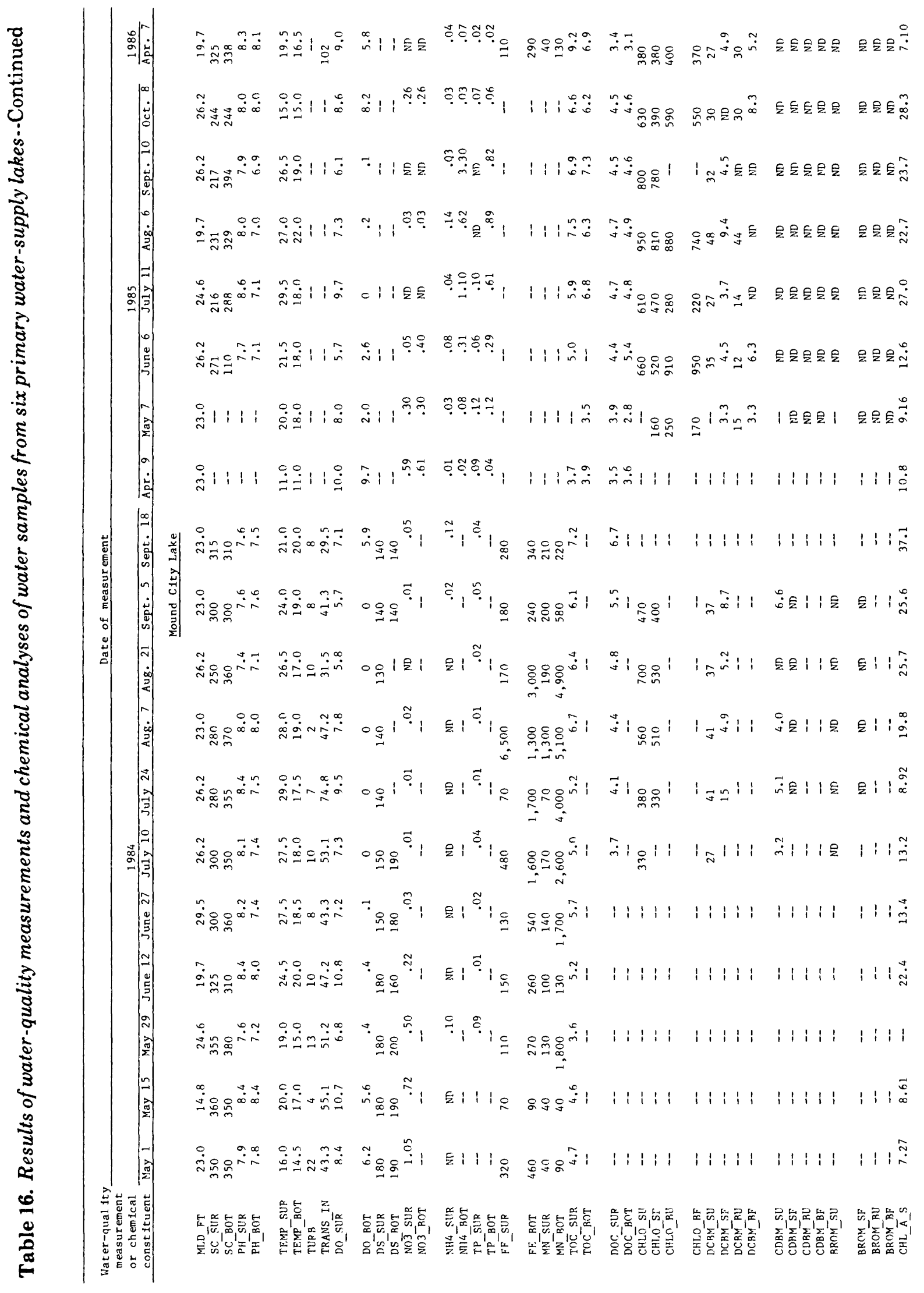




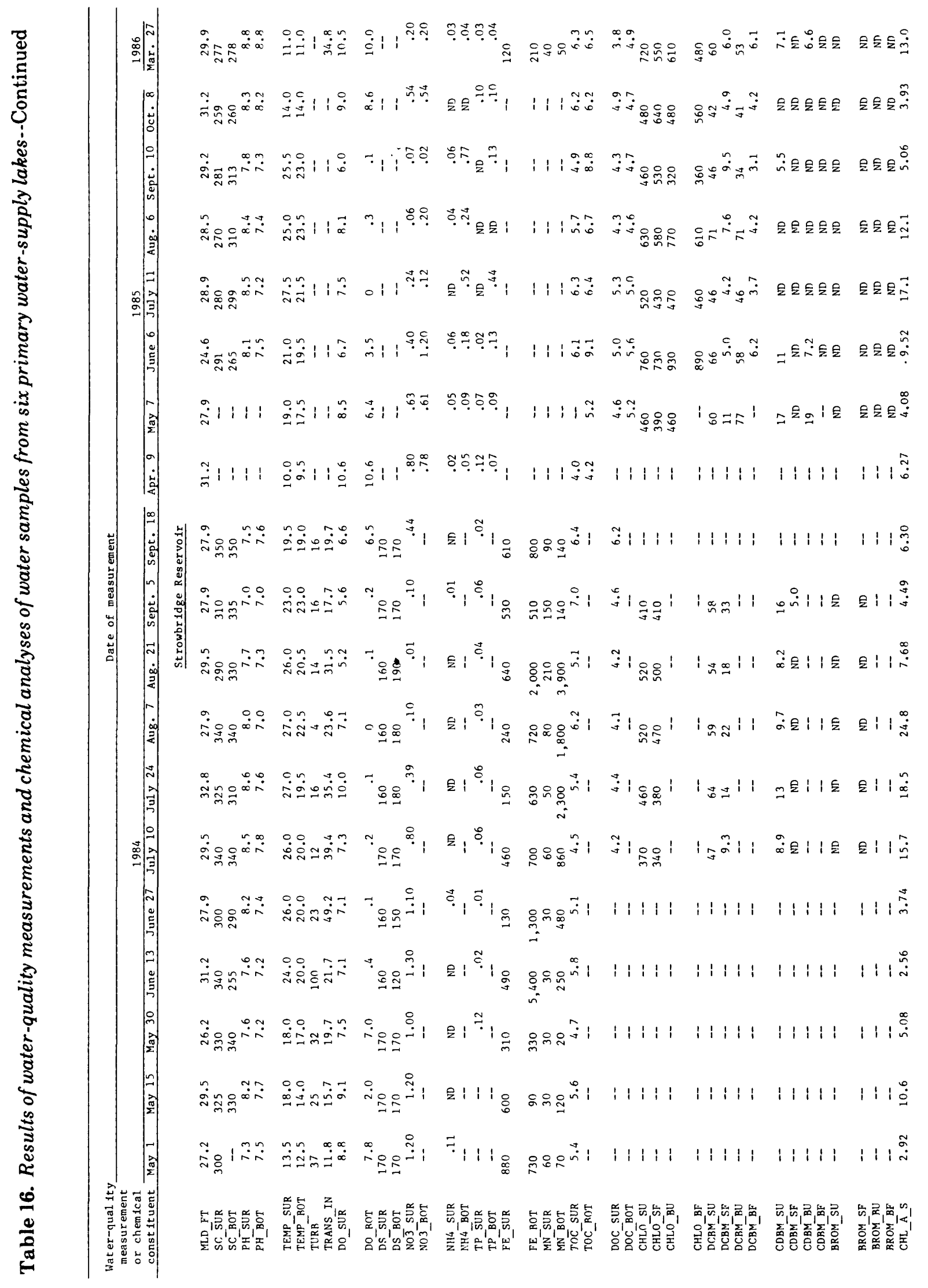




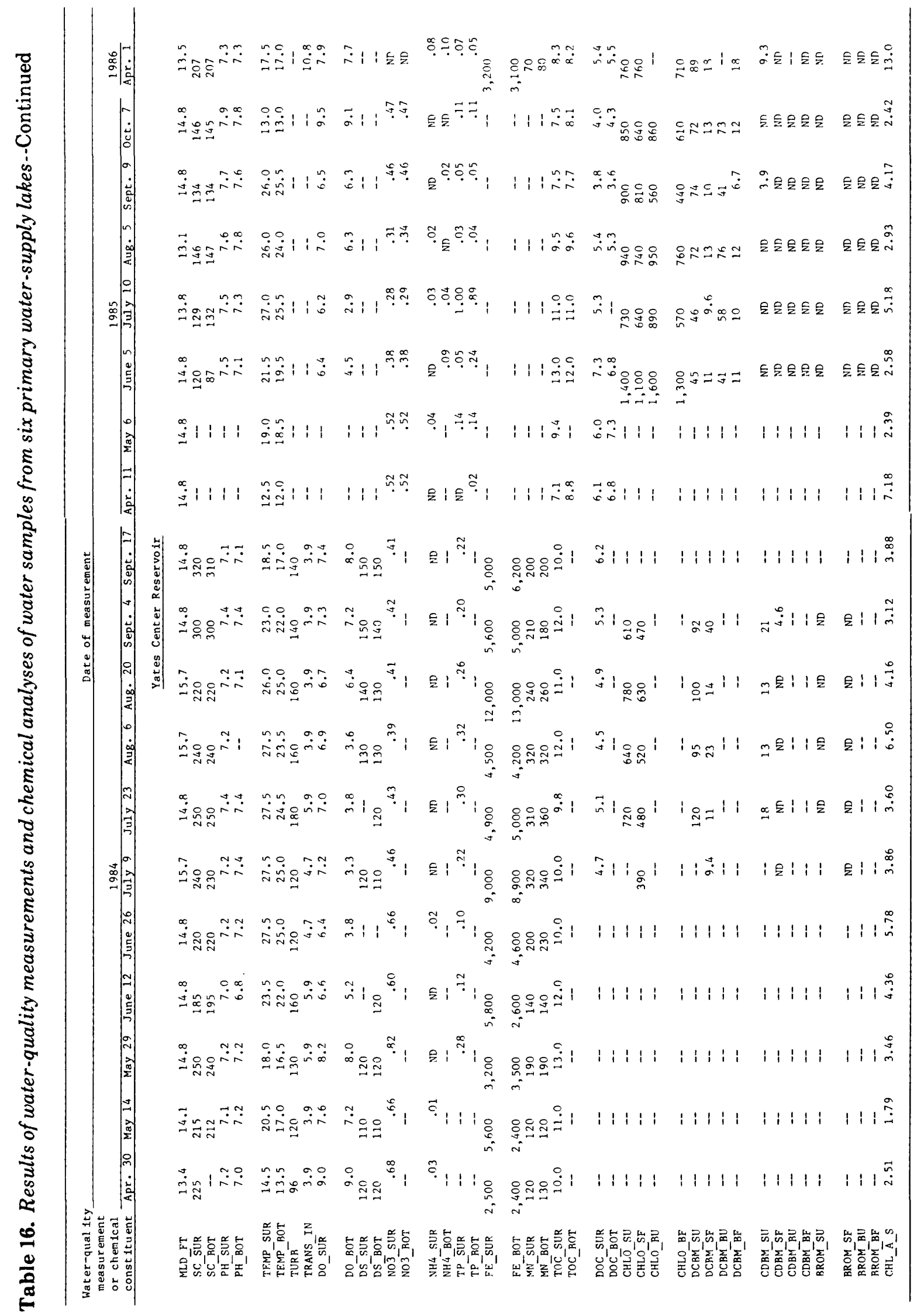


Table 17. Results of water-quality measurements and chemical analyses of water samples from nine supplementary water-supply lakes

[See table 5 for description of abbreviations; ND, not detected. --, not determined. See tables 3 and 4 for analytical detection limits.]

\begin{tabular}{|c|c|c|c|c|c|c|c|c|c|c|c|c|}
\hline \multirow{3}{*}{$\begin{array}{l}\text { Water-qual ity } \\
\text { measurement } \\
\text { or chemical } \\
\text { constituent }\end{array}$} & \multicolumn{12}{|c|}{ Date of measur ement } \\
\hline & \multicolumn{3}{|c|}{1985} & \multirow{2}{*}{$\frac{1986}{\text { Mar. } 31}$} & \multicolumn{3}{|c|}{1985} & \multirow{2}{*}{$\frac{1986}{\text { Mar. } 31}$} & \multicolumn{3}{|c|}{1985} & \multirow{2}{*}{$\frac{1986}{\mathrm{Apr} .8}$} \\
\hline & May 23 & Aug. 29 & Oct. 16 & & May 23 & Aug. 29 & Oct. 16 & & May 22 & Aug. 21 & Oct. 22 & \\
\hline & \multicolumn{4}{|c|}{ Al tamont West Lake } & \multicolumn{4}{|c|}{ Edna City Lake } & \multicolumn{4}{|c|}{ Her ington Reservoir } \\
\hline MLD_FT & 9.8 & 11.5 & 11.5 & 10.2 & 21.3 & 25.6 & 23.0 & 29.2 & 32.8 & 21.7 & - & 22.0 \\
\hline SC_SUR & 124 & 130 & 128 & 141 & 175 & 165 & 183 & 207 & 652 & 504 & 371 & 683 \\
\hline $\mathrm{SC}^{-} \mathrm{BOT}$ & -- & 132 & 130 & 141 & -- & 272 & 192 & 190 & - & 504 & - & 685 \\
\hline $\mathrm{PH}_{-}^{-} \mathrm{SUR}$ & 7.8 & 8.0 & 8.2 & 7.4 & 8.1 & 8.7 & 8.6 & 7.9 & 8.5 & 8.1 & 8.2 & 8.1 \\
\hline $\mathrm{PH}_{-}^{-} \mathrm{BOT}$ & -- & 7.3 & 7.8 & 7.6 & -- & 7.2 & 7.8 & 7.8 & -- & 8.0 & - & 8.1 \\
\hline TEMP_SUR & 21.5 & 25.5 & 18.0 & 17.5 & 22.5 & 26.5 & 18.0 & 18.0 & 20.0 & 24.0 & 14.5 & 15.5 \\
\hline TEMP BOT & - & 24.0 & 16.5 & 17.5 & -- & 14.0 & 15.5 & 11.0 & - & 23.5 & - & 15.0 \\
\hline TURB ${ }^{-}$ & -- & -- & - & - & -- & -- & -- & -- & -- & -- & -- & -- \\
\hline TRANS_IN & 14.0 & 25.2 & 14.4 & 12.0 & 68.0 & 69.6 & 66.0 & 68.4 & 32.0 & 19.2 & 16.8 & 19.2 \\
\hline DO_SUR & 7.1 & 7.2 & 7.3 & 8.6 & 7.5 & 7.6 & 9.2 & 8.4 & 8.8 & 6.5 & 8.5 & 6.5 \\
\hline DO BOT & -- & 1.2 & 6.1 & 8.5 & -- & 0 & 4.5 & 0.4 & -- & 5.7 & -- & 5.7 \\
\hline DS_SUR & -- & -- & -- & -- & -- & - & - & -- & -- & - & - & -- \\
\hline $\mathrm{DS}^{-} \mathrm{BOT}$ & -- & -- & -- & -- & -- & -- & -- & -- & -- & -- & -- & -- \\
\hline NO $\overline{3}$ _SUR & .20 & 1.10 & .10 & .30 & ND & ND & ND & ND & .50 & .40 & 1.30 & .70 \\
\hline NO3_BOT & -- & ND & .10 & .30 & -- & -- & $\mathrm{Nn}$ & ND & -- & .40 & - & .70 \\
\hline $\mathrm{NH}_{4}$ _SUR & .10 & .03 & .05 & .05 & .06 & .01 & .04 & .01 & .11 & .04 & .10 & .16 \\
\hline $\mathrm{NH}_{4}^{-}{ }^{-} \mathrm{BOT}$ & - & .16 & .06 & .04 & -- & -- & .16 & -- & -- & .04 & -- & .19 \\
\hline TP_s̄UR & .05 & .01 & .03 & .03 & .03 & ND & ND & .01 & .05 & .04 & .11 & .05 \\
\hline $\mathrm{TP}_{-}^{-} \mathrm{BOT}$ & -- & .02 & .03 & -- & -- & -- & .02 & .02 & - & .04 & - & .06 \\
\hline FE_SUR & 2,700 & 1,200 & 1,800 & 3,100 & 160 & 60 & 100 & 250 & 370 & 830 & 1,600 & 850 \\
\hline FE BOT & -- & 1,800 & 2,400 & 2,900 & -- & 80 & 1,600 & 390 & -- & 930 & -- & 1,000 \\
\hline MN_SUR & 40 & 50 & 50 & 40 & 40 & 60 & 70 & 60 & 70 & 130 & 50 & 80 \\
\hline MN_BOT & -- & 440 & 70 & 40 & --1 & 15,000 & 610 & 350 & -- & 140 & -- & 100 \\
\hline TOC̄__SUR & 7.7 & 6.1 & 10.0 & 7.9 & 5.3 & 5.2 & 8.6 & 6.6 & 8.6 & 4.9 & 4.7 & 7.1 \\
\hline TOC_BOT & -- & 5.6 & -- & 8.2 & - & 8.2 & -- & 5.4 & - & 4.7 & -- & 7.7 \\
\hline DOC_SUR & 6.0 & 5.1 & 5.6 & 4.8 & 5.1 & 5.4 & 5.1 & 4.3 & 5.9 & 3.9 & 5.0 & 4.5 \\
\hline $\mathrm{DOC}_{-\mathrm{BOT}}$ & - & 4.9 & 5.6 & 4.7 & -- & -- & 5.0 & 4.2 & -- & 3.9 & - & 3.5 \\
\hline $\mathrm{CHL}^{-}{ }_{\mathrm{SU}} \mathrm{SU}$ & -- & 600 & 790 & 850 & -- & 530 & 680 & 540 & -- & 220 & 760 & 480 \\
\hline $\mathrm{CHLO}-\mathrm{SF}$ & - & 580 & 790 & 580 & - & 450 & 590 & 520 & -- & 310 & 740 & 400 \\
\hline $\mathrm{CHLO}^{-} \mathrm{BU}$ & -- & 610 & 790 & -- & -- & -- & 600 & -- & -- & 420 & -- & 480 \\
\hline CHLO_BF & -- & 550 & 700 & -- & -- & -- & 520 & -- & - & 360 & -- & 440 \\
\hline DCBM_SU & -- & 23 & 26 & 31 & -- & 20 & 22 & 16 & -- & 80 & 120 & 170 \\
\hline DCBM_SF & -- & 6.4 & 7.9 & 14 & -- & 4.5 & 5.8 & 8.0 & -- & 74 & 15 & 91 \\
\hline $\mathrm{DCBM}=\mathrm{BU}$ & -- & 16 & 26 & -- & -- & 6.4 & 18 & -- & -- & 150 & - & 160 \\
\hline DCBM_BF & -- & 5.0 & 7.5 & -- & -- & 3.0 & 5.8 & -- & -- & 83 & -- & 79 \\
\hline CDBM_SU & -- & ND & ND & ND & -- & ND & ND & ND & -- & 42 & $16^{\circ}$ & 69 \\
\hline CDBM_SF & -- & ND & $\mathrm{ND}$ & $\mathrm{ND}$ & -- & ND & ND & ND & -- & 23 & ND & 22 \\
\hline $\mathrm{CDBM}_{-}^{-} \mathrm{BU}$ & -- & ND & ND & -- & -- & ND & ND & -- & -- & 100 & -- & 75 \\
\hline $\mathrm{CDBM}^{-} \mathrm{BF}^{-}$ & -- & ND & ND & -- & - & ND & ND & - & - & 17 & -- & 15 \\
\hline BROM_SU & -- & ND & ND & ND & -- & ND & ND & ND & -- & ND & ND & ND \\
\hline BROM SF & - & ND & ND & ND & - & ND & ND & ND & - & ND & ND & ND \\
\hline BROM_BU & -- & ND & $\mathrm{ND}$ & -- & -- & ND & ND & - & -- & SD & -- & ND \\
\hline $\mathrm{BROM}^{-} \mathrm{BF}$ & -- & ND & ND & -- & -- & ND & ND & -- & -- & ND & - & ND \\
\hline $\mathrm{CHL}_{-} \overline{\mathrm{A}}_{-} \mathrm{S}$ & 6.90 & 6.00 & 2.80 & 5.20 & 1.20 & 4.70 & 5.00 & 3.90 & 13.0 & 15.0 & 5.20 & 8.80 \\
\hline
\end{tabular}


Table 17. Results of water-quality measurements and chemical analyses of water samples from nine supplementary water-supply lakes--Continued

\begin{tabular}{|c|c|c|c|c|c|c|c|c|c|c|c|c|}
\hline \multirow{3}{*}{$\begin{array}{l}\text { Wat er-qual ity } \\
\text { measurement } \\
\text { or chemical } \\
\text { constituent }\end{array}$} & \multicolumn{12}{|c|}{ Date of measurement } \\
\hline & \multicolumn{3}{|c|}{1985} & \multirow{2}{*}{$\frac{1986}{\text { Mar. } 27}$} & \multicolumn{3}{|c|}{1985} & \multirow{2}{*}{$\frac{1986}{\text { Apr. } 21}$} & \multicolumn{3}{|c|}{1985} & \multirow{2}{*}{$\frac{1986}{\text { Mar. } 27}$} \\
\hline & May 24 & Aug. 27 & $\overline{\text { Oct. } 24}$ & & May 24 & Aug. 22 & 0ct. 17 & & May 21 & Aug. 27 & Oct. 21 & \\
\hline & \multicolumn{4}{|c|}{ Lyndon City Lake } & \multicolumn{4}{|c|}{ Mol ine Peservoir } & \multicolumn{4}{|c|}{ Osage City Reservolr } \\
\hline MLD FT & 27.9 & 30.2 & 30.2 & 28.5 & 16.4 & 16.7 & 18.0 & 18.4 & 11.5 & 11.8 & 12.5 & 12.8 \\
\hline SC S̄UR & 305 & 247 & 236 & 302 & 407 & 344 & 344 & 461 & 299 & 232 & 153 & 381 \\
\hline $\mathrm{SC}^{-}{ }_{\mathrm{BOT}}$ & - & 271 & 217 & 302 & - & 349 & 342 & 463 & - & 235 & 143 & 380 \\
\hline $\mathrm{PH}^{-}$SUR & 8.4 & 8.3 & 8.6 & 8.4 & 8.1 & 8.4 & 8.2 & 8.2 & 7.7 & 7.7 & 8.7 & 8.3 \\
\hline $\mathrm{PH}_{-\mathrm{BOT}}^{-}$ & -- & 7.4 & 8.2 & 8.4 & -- & 8.0 & 8.0 & 8.2 & - & 7.6 & 7.9 & 8.3 \\
\hline TEMP SUR & 22.0 & 23.5 & 17.0 & 12.5 & 22.5 & 25.5 & 15.5 & 15.0 & 20.0 & 22.5 & 15.0 & 14.5 \\
\hline TEMP-BOT & - & 21.5 & 12.5 & 11.5 & - & 25.0 & 14.5 & 15.0 & -- & 22.5 & 13.5 & 13.0 \\
\hline TURB ${ }^{-}$ & -- & - & -- & -- & -- & - & -- & - & -- & -- & -- & -- \\
\hline TRANS IN & 81.0 & 43.2 & 39.6 & 38.4 & 23.0 & 30.0 & 31.2 & 19.2 & 13.0 & 9.6 & 12.0 & 30.0 \\
\hline DO_SUR & 7.7 & 8.2 & 9.0 & 10.0 & 7.2 & 6.7 & 8.6 & 8.8 & 7.2 & 4.9 & 7.7 & 9.7 \\
\hline DO BOT & -- & 0 & 4.7 & 9.3 & - & 3.3 & 5.4 & 8.0 & - & 3.7 & 4.3 & 9.0 \\
\hline$D^{-}$SUR & -- & - & -- & -- & -- & -- & $-{ }^{-}$ & -- & - & -- & -- & - \\
\hline $\mathrm{DS}^{-\mathrm{BOT}}$ & -- & -- & -- & -- & -- & -- & -- & -- & -- & -- & -- & -- \\
\hline NO $\overline{3}$ SUR & .20 & ND & .20 & ND & .30 & ND & ND & .20 & 1.20 & .50 & .30 & ND \\
\hline NO3-BOT & - & $\mathrm{ND}$ & ND & ND & -- & ND & ND & .10 & - & .50 & .30 & ND \\
\hline NH4 SUR & .04 & .03 & .13 & .02 & $.1 n$ & .05 & .10 & .18 & .09 & .07 & .14 & .03 \\
\hline $\mathrm{NH}_{4}-\mathrm{BOT}$ & -- & .62 & .05 & .03 & -- & .09 & .17 & .18 & - & .07 & .15 & .03 \\
\hline TP SUR & .02 & ND & .05 & .01 & .04 & .03 & .04 & .04 & .11 & .12 & .18 & .04 \\
\hline $\mathrm{TP}_{\mathrm{BOT}}^{-}$ & - & .05 & .03 & .02 & -- & .03 & .05 & .04 & -- & .12 & .18 & .03 \\
\hline FE_SUR & 120 & 280 & 1,200 & $320^{\circ}$ & 800 & $670^{\circ}$ & $780^{\circ}$ & 1,400 & 2,400 & 4,000 & 3,400 & $240^{\circ}$ \\
\hline FE BOT & -- & 1,800 & 790 & 1,000 & - & 1,100 & 1,100 & 1,400 & - & 4,300 & 3,400 & 310 \\
\hline $\mathrm{MN}^{-}$SUR & 20 & 50 & 200 & 40 & 110 & 160 & 80 & 210 & 100 & 250 & 60 & 90 \\
\hline MN BOT & - & 2,400 & 30 & 70 & - & 370 & 190 & 220 & - & 290 & 60 & 70 \\
\hline TOC SUR & -- & 3.0 & 3.7 & 3.4 & 5.3 & 4.3 & 11.0 & 5.1 & 10.0 & 6.8 & 8.5 & 8.6 \\
\hline $\mathrm{TOC}_{-\mathrm{BOT}}^{-1}$ & - & 4.1 & 3.5 & 3.4 & - & 4.1 & 11.0 & 5.5 & - & 5.0 & 8.1 & 8.7 \\
\hline DOC SUR & 3.9 & 3.1 & 3.8 & 3.1 & 5.4 & 4.8 & 6.1 & 5.0 & 7.3 & 5.4 & 7.2 & 6.9 \\
\hline DOC BОT & -- & 3.7 & 3.8 & 3.0 & -- & 4.6 & 6.0 & 4.8 & $\because$ & - & 7.1 & 6.2 \\
\hline $\mathrm{CHL} \overline{\mathrm{O}} \mathrm{SU}$ & -- & 450 & 480 & 350 & -- & 360 & 830 & 550 & -- & 750 & 1,200 & 880 \\
\hline $\mathrm{CHLO}^{-} \mathrm{SF}$ & - & 450 & 460 & 360 & -- & 420 & 810 & 550 & -- & 620 & 1,000 & 730 \\
\hline $\mathrm{CHLO}^{-} \mathrm{BU}$ & -- & 640 & 520 & 400 & -- & 440 & 770 & 580 & -- & 860 & 1,100 & 880 \\
\hline CHLO BF & -- & 520 & 490 & 340 & -- & 420 & 730 & 550 & -- & -- & 1,100 & 810 \\
\hline DCBM SU & -- & 34 & 30 & 29 & -- & 61 & 110 & 98 & -- & 40 & 29 & 53 \\
\hline DCBM SF & -- & 7.2 & 6.7 & 5.5 & -- & 28 & 17 & 9.1 & - & 7.4 & 11 & 10 \\
\hline DCBM BU & -- & 35 & 26 & 29 & -- & 75 & 99 & 100 & -- & 41 & 27 & 49 \\
\hline $\mathrm{DCBM}$ & -- & 3.5 & 4.7 & 4.6 & -- & 12 & 11 & 8.5 & -- & - & 12 & 11 \\
\hline CDBM SU & -- & 3.2 & ND & ND & -- & ND & ND & 20 & -- & ND & ND & $\mathrm{ND}$ \\
\hline $\mathrm{CDRM}=\mathrm{SF}$ & - & ND & ND & ND & -- & ND & $\mathrm{NN}$ & ND & - & $\mathrm{ND}$ & ND & ND \\
\hline $\mathrm{CDRM}^{-} \mathrm{BU}$ & -- & ND & ND & ND & -- & 21 & $\mathrm{Nn}$ & 23 & -- & ND & ND & ND \\
\hline $\mathrm{CDRM}^{-} \mathrm{BF}$ & - & ND & ND & ND & -- & $\mathrm{ND}$ & ND & ND & -- & -- & ND & ND \\
\hline $\mathrm{BROM}^{-} \mathrm{SU}$ & -- & ND & $\mathrm{ND}$ & ND & -- & ND & ND & ND & -- & ND & ND & ND \\
\hline BROM SF & -- & $\mathrm{Nn}$ & ND & ND & -- & IND & ND & ND & -- & ND & ND & ND \\
\hline $\mathrm{BROM}_{-} \mathrm{BU}$ & -- & ND & ND & ND & -- & ND & ND & ND & -- & in & ND & ND \\
\hline BROM_BF & -- & ND & ND & ND & -- & $\mathrm{ND}$ & ND & ND & -- & -- & ND & ND \\
\hline CHL_A_S & .70 & - & 2.70 & 2.50 & 11.0 & 13.0 & 7.40 & 9.00 & 2.80 & 2.20 & .80 & 5.70 \\
\hline
\end{tabular}


Table 17. Results of water-quality measurements and chemical analyses of water samples from nine supplementary water-supply lakes--Continued

\begin{tabular}{|c|c|c|c|c|c|c|c|c|c|c|c|c|}
\hline \multirow{3}{*}{$\begin{array}{l}\text { Water-qual ity } \\
\text { measurement } \\
\text { or chemical } \\
\text { constituent }\end{array}$} & \multicolumn{12}{|c|}{ Date of measurement } \\
\hline & \multicolumn{3}{|c|}{1985} & 1986 & \multicolumn{3}{|c|}{1985} & \multirow{2}{*}{$\frac{1986}{\text { Apr. 1 }}$} & \multicolumn{3}{|c|}{1985} & \multirow{2}{*}{$\frac{1986}{\text { Apr. } 10}$} \\
\hline & May 21 & Aug. 20 & 0 ct. 15 & Apr. 7 & May 24 & Aug. 22 & Oct. 17 & & May 22 & Aug. 21 & Oct. 21 & \\
\hline & \multicolumn{4}{|c|}{ P1 easanton East City Lake } & \multicolumn{4}{|c|}{ Polk Daniels Lake } & \multicolumn{4}{|c|}{ Prairie Lake } \\
\hline MLD FT & 27.9 & 30.5 & 29.5 & 26.6 & 14.8 & 20.7 & 17.1 & 17.1 & 21.3 & 23.0 & 27.9 & 28.9 \\
\hline SC_S SUUR & 170 & 168 & 169 & 174 & 277 & 247 & 258 & 311 & 285 & 223 & 216 & 270 \\
\hline $\mathrm{SC}_{\mathrm{BOT}}^{-\mathrm{T}}$ & - & 250 & 172 & 183 & -- & 269 & 256 & 311 & - & 179 & 223 & 278 \\
\hline $\mathrm{PH}^{-} \mathrm{SUR}$ & 7.8 & 7.9 & 8.2 & 8.1 & 8.0 & 8.1 & 8.1 & 8.0 & 8.5 & 8.7 & 8.3 & 8.0 \\
\hline $\mathrm{PH}_{-}^{-} \mathrm{BOT}$ & - & 7.3 & 7.6 & 7.7 & -- & 7.3 & 7.6 & 8.0 & - & 7.5 & 7.7 & 7.7 \\
\hline TEMP SUR & 22.0 & 25.5 & 15.1 & 19.5 & 24.0 & 25.5 & 16.0 & 17.0 & 22.0 & 23.5 & 16.0 & 16.0 \\
\hline TEMP_BOT & - & 17.5 & 14.5 & 16.5 & - & 22.0 & 14.0 & 17.0 & - & 22.0 & 12.5 & 14.5 \\
\hline TURB $^{-}$ & -- & -- & - & - & -- & - & - & - & -- & -- & - & - \\
\hline TRANS_IN & 39.0 & 34.8 & 36.0 & 32.4 & 34.0 & 43.2 & 31.2 & 51.6 & 4.2 & 19.2 & 38.4 & 57.6 \\
\hline DO_SUR & 8.6 & 5.5 & 8.2 & 8.8 & 7.1 & 6.3 & 7.2 & 7.8 & 8.6 & 7.8 & 8.9 & 7.6 \\
\hline DO BOT & - & 0 & 4.7 & 4.6 & - & 0 & 1.6 & 7.3 & -- & 1.2 & 2.0 & 2.2 \\
\hline DS_SUR & -- & -- & -- & $\cdots$ & -- & - & -- & -- & -- & -- & -- & - \\
\hline DS ${ }^{-}$OT & -- & -- & - & -- & -- & -- & -- & -- & -- & -- & -- & -- \\
\hline N0 3 SUR & .20 & ND & .20 & .10 & .20 & ND & .30 & ND & .40 & ND & .20 & .30 \\
\hline NO3_BOT & - & ND & .20 & .20 & -- & $\mathrm{ND}$ & .30 & ND & -- & .10 & .10 & .20 \\
\hline NH4_SUR & .05 & .05 & .05 & ND & .06 & .03 & .05 & .02 & .12 & .05 & .14 & .10 \\
\hline $\mathrm{NH}_{4}-\mathrm{BOT}$ & -- & 2.10 & .28 & .29 & -- & .53 & .10 & .13 & -- & .34 & .77 & .44 \\
\hline TP_S̄UR & .03 & .01 & .02 & .04 & .03 & .02 & .03 & .02 & .03 & .07 & .06 & .05 \\
\hline $\mathrm{TP}_{-\mathrm{BOT}}^{-\mathrm{T}}$ & -- & .15 & .06 & .06 & -- & .05 & .04 & .02 & -- & .12 & .13 & .08 \\
\hline FE_SUR & 220 & 250 & 420 & 420 & 330 & 280 & 690 & 340 & 200 & 380 & 710 & 230 \\
\hline FE_BOT & -- & 5,300 & 2,100 & 620 & -- & 1,600 & 1,100 & 320 & -- & 1,200 & 1,300 & 410 \\
\hline $\mathrm{MN}^{-} \mathrm{SUR}$ & 50 & 110 & 60 & 80 & 60 & 40 & 40 & 50 & 50 & 120 & 40 & 40 \\
\hline MN-BOT & -- & 7,500 & 610 & 170 & -- & 2,300 & 140 & 80 & -- & 220 & 580 & 460 \\
\hline TOC̄_SUR & 6.9 & 4.9 & 8.9 & 10.0 & 5.1 & 4.5 & 11.0 & 5.9 & 6.0 & 5.4 & 9.5 & 8.7 \\
\hline $\mathrm{TOC}$ BOT & -- & 7.1 & 10.0 & 7.8 & -- & 4.7 & 9.5 & 6.3 & - & 10.0 & 8.0 & 11.0 \\
\hline DOC_SUR & 5.4 & 4.9 & 4.7 & 5.0 & 4.3 & 4.4 & 6.4 & 4.7 & 5.4 & 5.5 & 6.8 & 5.6 \\
\hline DOC_BOT & - & 6.2 & 4.9 & 5.4 & -- & 4.9 & 6.2 & 4.3 & -- & 5.4 & 6.6 & 5.7 \\
\hline $\mathrm{CHL} \overline{0} \mathrm{SU}$ & -- & -- & 600 & 680 & 620 & 670 & 940 & 670 & -- & 680 & 1,000 & 820 \\
\hline CHLO $-S F$ & -- & -- & 680 & 570 & - & 740 & 840 & 600 & -- & 540 & 840 & 700 \\
\hline $\mathrm{CHLO}^{-} \mathrm{BU}$ & -- & -- & 680 & 670 & -- & 440 & 870 & 660 & -- & 630 & 910 & 790 \\
\hline CHLO BF & - & - & 600 & 690 & -- & 400 & 800 & 540 & -- & 630 & 760 & 720 \\
\hline $\mathrm{DCBM}^{-} \mathrm{SU}$ & -- & -- & 33 & 37 & 25 & 30 & 38 & 41 & - & 33 & 44 & 44 \\
\hline DCBM SF & -- & -- & 5.3 & 8.4 & -- & 8.2 & 11 & 14 & -- & 7.0 & 8.1 & 11 \\
\hline DCBM BU & -- & -- & 35 & 37 & -- & 16 & 32 & 36 & -- & 24 & 33 & 41 \\
\hline DCBM_BF & -- & -- & 5.6 & 9.7 & -- & 3 & 10 & 13 & -- & 4.2 & 6.7 & 10 \\
\hline CDBM_SU & -- & -- & ND & ND & ND & ND & ND & ND & -- & 3.1 & ND & $\mathrm{ND}$ \\
\hline $\mathrm{CDBM}^{-} \mathrm{SF}$ & -- & -- & ND & ND & -- & $\mathrm{ND}$ & ND & ND & - & ND & ND & ND \\
\hline $\mathrm{CDBM}^{-} \mathrm{BU}^{-}$ & -- & -- & ND & ND & -- & Dיו & ND & ND & -- & IND & ND & ND \\
\hline CDBM BF & -- & -- & $\mathrm{ND}$ & ND & -- & ND & NN & ND & -- & ND & ND & ND \\
\hline $\mathrm{BROM}^{-} \mathrm{SU}$ & -- & -- & IN & $\mathrm{ND}$ & ND & ND & ND & ND & -- & ND & ND & $\mathrm{ND}$ \\
\hline BROM SF & -- & -- & ND & ND & - & $\mathrm{ND}$ & $\mathrm{Nn}$ & ND & - & ND & $\mathrm{Nn}$ & ND \\
\hline $\mathrm{BROM}^{-} \mathrm{BU}$ & -- & -- & $\mathrm{ND}$ & $\mathrm{ND}$ & -- & ND & in & ND & -- & in & חא & ND \\
\hline BROM BF & -- & -- & ND & $\mathrm{ND}$ & -- & ND & ND & ND & - & $\mathrm{ND}$ & $\mathrm{ND}$ & ND \\
\hline $\mathrm{CHL}_{-} \overline{\mathrm{A}}-\mathrm{S}$ & 5.90 & 4.50 & 5.90 & 18.0 & 7.40 & 11.0 & 3.30 & 3.60 & -- & 54.0 & 15.0 & 11.0 \\
\hline
\end{tabular}

